
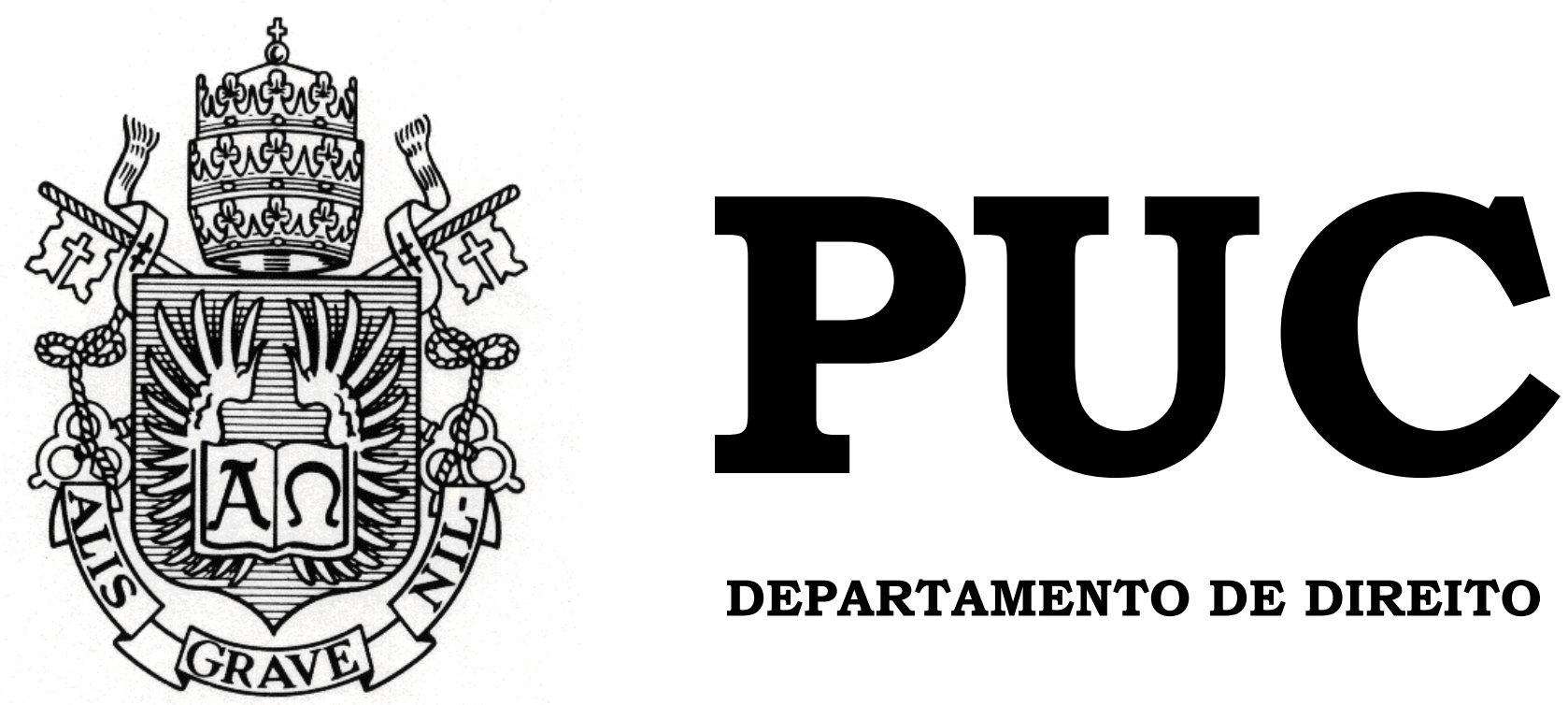

DEPARTAMENTO DE DIREITO

O PRINCÍPIO DA AUTONOMIA DA VONTADE NA CONVENÇÃO DAS NAÇÕES UNIDAS SOBRE CONTRATOS DE COMPRA E VENDA INTERNACIONAL DE MERCADORIAS: UMA VISÃO DOUTRINÁRIA E JURISPRUDENCIAL

por

VANESSA MONTERO MOIRE CHALHOUB

ORIENTADORA: NÁDIA DE ARAÚJO

2019.1

PONTIFÍCIA UNIVERSIDADE CATÓLICA DO RIO DE JANEIRO

RUA MARQUÊS DE SÃO VICENTE, 225 - CEP 22453-900

RIO DE JANEIRO - BRASIL 


\section{O PRINCÍPIO DA AUTONOMIA DA VONTADE NA CONVENÇÃO DAS NAÇÕES UNIDAS SOBRE CONTRATOS DE COMPRA E VENDA INTERNACIONAL DE MERCADORIAS: UMA VISÃO DOUTRINÁRIA E JURISPRUDENCIAL}

por

VANESSA MONTERO MOIRE CHALHOUB

Monografia

apresentada

ao

Departamento de Direito da Pontificia Universidade Católica do Rio de Janeiro (PUC-Rio) como requisito parcial para a obtenção do Título de Bacharel em Direito.

Orientadora: Nádia de Araújo 
Aos meus avós, Mercedes e Jesus, saudades eternas. 


\section{AGRADECIMENTOS}

Em primeiro lugar, agradeço aos meus pais, Márcio e Verônica, que sempre me orientaram, apoiaram e me fizeram enxergar o poder da educação e tudo que ela pode nos proporcionar. Obrigada por todo o amor e dedicação.

Aos meus avós, Nabih e Ermelinda, pelo carinho.

Aos meus amigos, que alegram meus dias, vibram com as minhas vitórias e me levantam nas derrotas; que compartilham comigo absolutamente todos os momentos. Fico muito feliz em escrevermos juntos a história das nossas vidas. É uma honra ter vocês ao meu lado.

A todos aqueles que já foram meus professores, tanto no ensino básico quanto na Graduação. Obrigada por escolherem esse ofício tão essencial para o desenvolvimento de qualquer ser humano. Obrigada por ensinarem seus alunos da melhor forma possível. Obrigada por contribuírem para que eu esteja aqui hoje, bem como para que tantos outros jovens encontrem, através da educação, um futuro digno e respeitável.

Em especial, agradeço à Nádia de Araújo, minha professora de Direito Internacional Privado ainda no $8^{\circ}$ período - quando me encantei pelo tema - e que gentilmente concordou em me orientar neste trabalho. Obrigada pela atenção, pelas observações certeiras e objetivas, pelos conselhos e por partilhar seu conhecimento e se dedicar junto comigo na elaboração dessa monografia. Foi um aprendizado enorme.

Agradeço, ainda, aos meus companheiros de trabalho - do Bichara Advogados, Procuradoria Geral da Fazenda Nacional e, finalmente, da SPOT Educação. Obrigada por me ensinarem tanto, por me apoiarem e me ajudarem a crescer profissionalmente.

Finalmente, obrigada a todos que de alguma forma contribuíram para que eu esteja aqui hoje, um passo mais perto de atingir meus objetivos. 


\section{RESUMO}

O presente trabalho tem por objetivo analisar o princípio da autonomia da vontade no âmbito da Convenção das Nações Unidas para a Compra e Venda Internacional de Mercadorias (CISG). Para esse propósito, foi estudado o princípio da autonomia da vontade, sua origem histórica e aplicabilidade em relação ao direito doméstico e internacional. Posteriormente, passa-se a analisar a questão do ponto de vista específico da CISG, levando em consideração a importância atribuída pela Convenção ao referido princípio notadamente em seu artigo 6. Por fim, é exposta a visão da jurisprudência de cortes de diversos países sobre a aplicabilidade da Convenção, de modo a demonstrar como a manifestação da autonomia da vontade das partes na escolha da lei aplicável aos contratos internacionais é enfrentada pelos tribunais de diferentes jurisdições.

Palavras-chave: CISG. Autonomia da Vontade. Direito Civil. Direito Internacional Privado. Comércio Internacional. Contratos Internacionais. Lei aplicável. Doutrina. Jurisprudência. 


\begin{abstract}
This study aims to analyze the principle of party autonomy under the scope of the CISG. In order to do this, first, the principle was studied along with its historical origins and application in both domestic and international law. Afterwards, in a more specific approach, this matter is examined under the perspective of the Convention, taking into consideration the importance given to the principle by the CISG - especially when it comes to its article 6. Finally, the jurisprudence of several countries' courts on the applicability of the CISG is displayed, in order to reveal how the manifestation of party autonomy in the clause of choice of law is faced by the tribunals of different jurisdictions.
\end{abstract}

Key-words: CISG. Party Autonomy. Civil Law. Private International Law. International Trade. International Contracts. Applicable law. Doctrine. Jurisprudence. 


\section{SUMÁRIO}

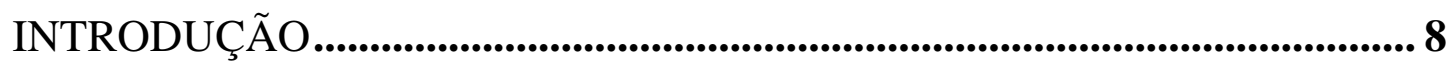

CAPÍTULO 1 - O PRINCÍPIO DA AUTONOMIA DA VONTADE ............11

1.1 Conceito, histórico e aplicabilidade no âmbito dos contratos

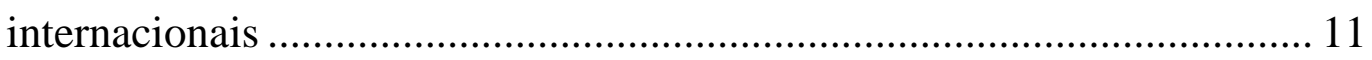

1.2 O princípio no ordenamento jurídico brasileiro ................................. 22

CAPÍTULO 2 - A CONVENÇÃO DAS NAÇÕES UNIDAS SOBRE CONTRATOS DE COMPRA E VENDA INTERNACIONAL DE MERCADORIAS (CISG) ............................................................................................ 26

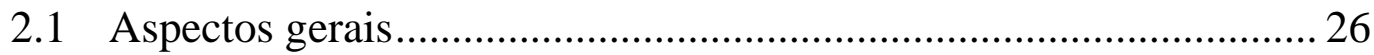

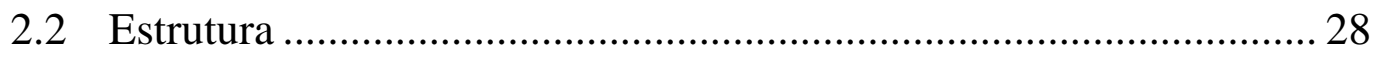

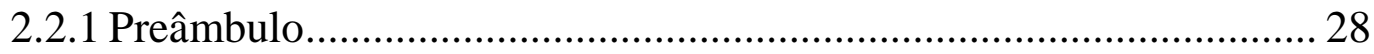

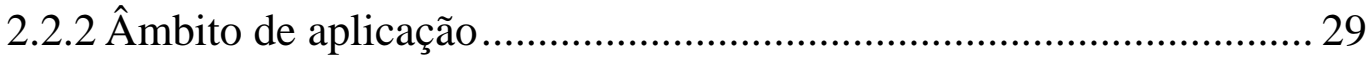

2.2.3 Princípios e disposições relevantes ...................................................... 32

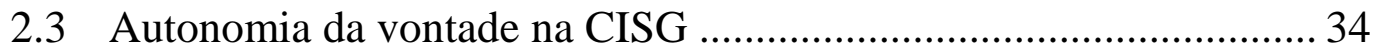

CAPÍTULO 3 -ESTUDO DE CASOS......................................................................3 37

3.1 Casos nos quais foi reconhecida a aplicação da CISG........................37

3.2 Casos nos quais foi reconhecida a inaplicabilidade da CISG ........... 45

3.3 Casos em que foi reconhecida a aplicação parcial da CISG .............. 51

CONSIDERAÇÕS FINAIS.................................................................................52

REFERÊNCIAS BIBLIOGRÁFICAS ........................................................57 


\section{LISTA DE ABREVIATURAS E SIGLAS}

CISG Convenção das Nações Unidas sobre os Contratos de Compra

e Venda de Mercadorias

CLOUT Case Law on UNICTRAL Texts

HCCH Conferência da Haia sobre Direito Internacional Privado

INCOTERMS Termos Comerciais de Comércio

LICC Lei de Introdução ao Código Civil

LINDB Lei de Introdução ao Direito Brasileiro

ONU Organização das Nações Unidas

STF Superior Tribunal Federal

UNCITRAL Comissão das Nações Unidas para o Direito Comercial

Internacional

UNIDROIT Instituto Internacional para a Unificação do Direito Privado 


\section{INTRODUÇÃO}

As relações de comércio estão presentes na história da humanidade desde os seus primórdios, na antiguidade, sendo certo que as partes sempre tiveram liberdade para contratar, isto é, liberdade ao conduzir as negociações envolvidas nas transações comerciais.

Fato é que as relações de comércio evoluíram junto às civilizações e a medida em que os Estados Nacionais se estruturaram, e o comércio passou a ser regulamentado em cada um deles, as relações internacionais passaram a utilizar contratos internacionais, e desde meados do século XIX, em decorrência da intensificação das relações estabelecidas entre agentes de diferentes países, esses se tornaram mais comuns.

A partir da introdução do navio a vapor, que acarretou a profissionalização do transporte marítimo de cargas, no século XIX, a compra e venda de mercadorias passou a ser mais ágil e eficaz, e permitiu o maior desenvolvimento do transporte à distância. ${ }^{1}$

No século XX, aumentaram as relações de comércio e a globalização, e com os novos avanços tecnológicos responsáveis por encurtar distâncias e facilitar a comunicação interfronteiras, foi intensificada a necessidade de contar com regulamentações uniformes, em nível internacional.

O objetivo das organizações internacionais de direito privado, ao elaborar regulamentações para o comércio internacional, era (e ainda é) claro: facilitar progressivamente essa atividade, através da garantia de segurança jurídica e previsibilidade a seus agentes, para que deixassem de ser reféns de regulamentações domésticas que divergiam e conflitavam entre si - o que gerava uma situação de caos jurídico diante de conflitos que pudessem surgir

\footnotetext{
${ }^{1}$ ARAUJO, Nádia de. Direito Internacional Privado: teoria e prática brasileira. Rio de Janeiro: Renovar, 2011, p. 358.
} 
entre as partes contratantes e freava o desenvolvimento das atividades por ela exercidas.

O destaque desse trabalho é a Convenção das Nações Unidas para a Compra e Venda Internacional de Mercadorias (CISG), que representa o ápice do movimento de uniformização de regras relativas aos contratos internacionais de compra e venda de mercadorias.

A CISG é considerada um avanço em direção à unificação do direito positivo sobre o tema em nível internacional, e teve expressiva adesão de Estados ao seu texto desde o seu surgimento, em 1980.

Em 2019, a CISG conta com 89 Estados signatários ${ }^{2}$, que representam, juntos, mais de $80 \%$ das transações de mercadorias internacionais. É, sem dúvida, um instrumento uniforme que conseguiu harmonizar as regras de direito privado no tema da compra e venda internacional.

O que se verá a seguir é, portanto, a dinâmica da referida Convenção à luz de um dos principais motivos para sua ampla adesão: a importância conferida por ela ao princípio da autonomia da vontade.

Para isso, estruturou-se o presente trabalho em três capítulos.

O primeiro deles trata do princípio da autonomia da vontade, conceituando-o a luz do Direito Civil, trazendo sua trajetória histórica sob a ótica doutrinária e jurisprudencial e elucidando sua importância para o Direito Internacional Privado, no que diz respeito à escolha da lei aplicável às relações internacionais privadas. O capítulo traz, ainda, o princípio no ordenamento jurídico brasileiro, conforme abordado pela LINDB, bem como pela Lei de Arbitragem e pela Convenção de Viena de 1980.

\footnotetext{
${ }^{2}$ Status

United Nations Convention on Contracts for the International Sale of Goods (Vienna, 1980). Uncitral. Disponível em: <http://www.uncitral. org/uncitral/uncitral_texts/ sale _ goods/1980CISG_status.html>. Acesso: 15 abr. 2019.
} 
O segundo capítulo traz considerações sobre a CISG, incluindo sua organização estrutural, seus principais dispositivos e princípios envolvidos na sua aplicação. Posteriormente, passa-se a analisar especificamente o tratamento conferido ao princípio da autonomia da vontade na Convenção.

Finalmente, a proposta do terceiro capítulo é a de estudar casos em que foi verificada ou não a aplicabilidade da CISG - ou ainda, a sua aplicação parcial - julgados por cortes de diversas jurisdições, de modo a demonstrar como se dá o entendimento dos tribunais sobre a manifestação de vontade das partes quanto à incidência da Convenção.

$\mathrm{Na}$ conclusão, serão abordados os principais pontos trabalhados ao longo do presente estudo, a fim de estabelecer um panorama geral sobre a autonomia da vontade, a CISG e sua eficácia em âmbito internacional, além de apresentar considerações acerca do que se espera para os próximos anos em relação à sua aplicação tanto pelos agentes do comércio internacional quanto pelos tribunais. 


\section{CAPÍTULO 1 - O PRINCÍPIO DA AUTONOMIA DA VONTADE}

\subsection{Conceito, histórico e aplicabilidade no âmbito dos contratos internacionais}

O princípio da autonomia da vontade ${ }^{3}$, no Direito Civil, está relacionado à esfera de liberdade das partes nas relações de direito privado, de se auto regerem através da escolha do tipo de contrato que melhor lhes convém, determinando sua forma, conteúdo e efeitos. Esta autonomia permite aos particulares criar, nos limites da lei, normas jurídicas aplicáveis ao vínculo jurídico entre eles estabelecido. ${ }^{4}$

Caio Mário da Silva Pereira esclarece que, no direito privado, "vigora o princípio da autonomia da vontade, e, nesta órbita, são supletivos ou meramente permissivos os princípios legais, salvo, entretanto, no que o legislador entende interessar à ordem pública, ponto onde começa a incidência das normas inderrogáveis pela vontade privada". 5

Caio Mário, ainda no âmbito do Direito Civil, ao tratar de atos e negócios jurídicos, ensina que as ações humanas, fruto da vontade de seus agentes e em conformidade com o ordenamento jurídico, constituem negócios jurídicos - ou atos jurídicos strictu sensu, conforme nomenclatura utilizada pela doutrina tradicional.

\footnotetext{
3 A autonomia da vontade é também denominada autonomia privada no Direito Civil. Ela "problematiza as relações entre a vontade e a norma", originando entendimentos doutrinários diversos, polarizados pela natureza subjetiva da vontade - que enaltece os interesses do agente - e o caráter objetivo da norma, que prioriza os interesses gerais da comunidade.

AMARAL NETO, Francisco dos Santos. A autonomia privada como princípio fundamental da ordem jurídica. Perspectivas estrutural e funcional. Revista de Informação Legislativa, Brasília, v. 26, n. 102, p. 207-230, 1989.

${ }^{4}$ BASSO, Maristela. A Autonomia da Vontade nos Contratos Internacionais do Comércio. Revista da Faculdade de Direito da UFRGS, v. 12, p. 198, 1996.

${ }^{5}$ PEREIRA, Caio Mário da Silva. Instituições de Direito Civil: introdução ao direito civil. 24. ed. Rio de Janeiro: Forense, 2011, p. 89.
} 
Sobre a vontade, o autor frisa que "o princípio pelo qual se lhe reconhece o poder criador de efeitos jurídicos denomina-se autonomia da vontade, que se enuncia por dizer que o indivíduo é livre de, pela declaração de sua própria vontade, em conformidade com a lei, criar direitos e contrair obrigações." 6

Neste sentido, existe uma manifestação de vontade para a formação de todo ato ou negócio jurídico e, certamente, no direito privado, o contrato é a maior expressão dessa autonomia da vontade do indivíduo.

Amaral Neto separa os conceitos de autonomia privada e autonomia da vontade - tratados por alguns autores como sinônimos -, por entender que se trata de conceitos distintos. Compreende que a primeira "significa o poder particular de criar relações jurídicas de que se participa", constituindo verdadeiro "poder jurídico de criar, modificar ou extinguir situações jurídicas próprias", enquanto a autonomia da vontade teria uma "conotação subjetiva, psicológica". 7

Os contratos internacionais são aqueles nos quais as partes contratantes podem ter, entre outros elementos, nacionalidades diversas e domicílio em países distintos. Também no que diz respeito ao objeto e execução, a mercadoria ou serviço contratado é entregue ou prestado além fronteiras, ou, ainda, quando os lugares de celebração e execução das obrigações contratuais não coincidem - ou seja, quando os elementos constitutivos do contrato se originam e se realizam fora dos limites geográfico-políticos de um único Estado. ${ }^{8}$

\footnotetext{
${ }^{6}$ PEREIRA, Caio Mário da Silva. Op. Cit., p. 400.

${ }^{7}$ AMARAL NETO, Francisco dos Santos. Op. Cit.

${ }^{8}$ STRENGER, Irincu. Contratos internacionais do comércio. São Paulo: Revista dos Tribunais, 1992, p. 24 .
} 
Segundo Nádia de Araujo, o que classifica um contrato como internacional é a existência de um elemento de estraneidade, isto é, "um elemento que o ligue a dois ou mais ordenamentos jurídicos". 9

Nos contratos internacionais, o princípio da autonomia da vontade desempenha papel de especial importância, tendo em vista que essa espécie contratual "traz em seu bojo a potencialidade de estar enquadrados em mais de um sistema jurídico". ${ }^{10}$ Por conta disso, é relevante que as partes definam qual será a lei aplicável ao contrato, bem como qual será a jurisdição e foro competentes, caso algum conflito se origine das estipulações contratuais.

Em relação à lei aplicável, está-se diante de uma definição de direito material, enquanto a escolha do foro está ligada ao direito processual. A grande diferença entre os contratos internos e internacionais, neste ponto, é que ambos têm a faculdade de definir o foro - ou, como vem sendo cada vez mais comum recentemente, a opção pela jurisdição arbitral - para eventual resolução de controvérsias oriundas do contrato, enquanto a escolha da lei aplicável é uma faculdade concedida tão somente aos contratos internacionais. ${ }^{11}$

Kahn-Freund entende que a "autonomia" tem dois significados no Direito Internacional Privado. ${ }^{12}$

\footnotetext{
9 ARAUJO, Nádia de. Direito Internacional Privado: teoria e prática brasileira. Rio de Janeiro: Renovar, 2011, p. 384.

${ }^{10}$ ROVIRA, Suzan Lee Zaragoza de. Estudo comparativo sobre os contratos internacionais: aspectos doutrinários e práticos. In: RODAS, João Grandino (Coord.) Contratos Internacionais. 2. ed. São Paulo: Revista dos Tribunais, 1995.

11 "No contrato internacional, devido a sua característica de estar ligado a mais de um sistema jurídico, é preciso saber de qual desses sistemas será a lei aplicável. E hoje a faculdade das partes em determinar esta escolha é pacífica em vários países, seja por força de legislação interna, ou ainda de normas provenientes de tratados e convenções internacionais que abraçaram o princípio."

ARAÚJO, Nádia de. A Autonomia da Vontade nos Contratos Internacionais - Direito Brasileiro e Países do Mercosul: Considerações sobre a Necessidade de Alterações no Direito Internacional Privado. Revista da Faculdade de Direito da UFRGS, v. 17, 1999, p. 226.

${ }^{12}$ KAHN-FREUND, O. General problems of private international law. Collected Courses of the Hague Academy of International Law. The Hague: Martinus Nijhoff, 1974. v. 143. p. 342.
} 
Em sentido mais amplo, ela se revela na possibilidade de as partes, ao escolherem um elemento de conexão, poderem, em certas situações, determinar a lei aplicável àquela relação. Significa dizer que, caso as partes escolham o local em que farão uma incorporação, determinarão, indiretamente, a lei aplicável a essa operação.

Outra interpretação para o referido termo em DIPri - sendo essa a que afeta o presente trabalho -, é a que diz respeito às partes escolherem diretamente a lei que governará a validação, interpretação e efeitos do contrato.

Ainda segundo Kahn-Freund, o exercício dessa autonomia em sentido mais estrito tem o propósito de antecipar a escolha da lei aplicável. Assim, é possível às partes calcular com mais propriedade os riscos envolvidos na execução daquele contrato, já que podem assumir "ex ante" qual será a lei aplicada àquela relação.

Nota-se que, caso essa escolha não fosse feita antecipadamente, a análise de risco não seria viável, já que só se conheceria a lei aplicável "ex post" - conforme fosse definido pelo juízo diante de um conflito entre as partes. $^{13}$

Essa autonomia para escolha da legislação aplicável ao contrato encontra limites nas normas de Direito Internacional Privado, originadas de tratados e convenções internacionais, bem como de ordenamentos jurídicos internos, que também contêm regulamentações para os negócios jurídicos celebrados em âmbito internacional, que envolvam algum elemento relacionado ao sistema jurídico daquele Estado.

\footnotetext{
${ }^{13}$ Importa esclarecer que, apesar de reconhecer o objetivo das partes ao estabelecerem previamente e de maneira objetiva a lei aplicável ao contrato, Kahn-Freund fez duras críticas à efetividade dessa escolha, pois entendia que a escolha da lei não bastava, já que poderia não ser acatada pelo tribunal responsável por julgar qualquer conflito que pudesse se originar daquela relação contratual. É o que se depreende de trecho de seu curso da Haia, de 1974: "The choice of law depends on the lex fori and on nothing else - this attempt to overcome the contextual aspect of private international law, to create harmony and to avoid conflicts decisions ex post is a snare and an illusion."
} 
No ordenamento jurídico brasileiro, por exemplo, a regra geral determina que os contratos internacionais obedeçam a lei do local de sua celebração. Dito isso, caso essa lei permita a autonomia da vontade das partes na escolha da lei aplicável, esta será viável, como será visto com mais detalhes adiante.

A nível internacional, pode-se citar os esforços da Conferência da Haia sobre Direito Internacional Privado $(\mathrm{HCCH})$, que resultaram na elaboração dos princípios $^{14}$ para escolha da lei aplicável aos contratos internacionais de comércio, cujo objetivo principal é promover a autonomia da vontade das partes a nível internacional. ${ }^{15}$

Historicamente, Charles Dumoulin é o jurista reconhecido pela doutrina como precursor do princípio da autonomia da vontade. Isto porque, ainda no século XVI, o advogado francês elaborou o primeiro parecer em defesa do referido princípio.

À ocasião, Dumoulin havia sido consultado por um casal francês, que questionou se a lei aplicável aos bens do seu patrimônio seria a do local onde se encontravam os imóveis ou a do domicílio do casal. Diante disso, o jurista desenvolveu o entendimento de que a lei aplicável seria aquela convencionada pelas partes, ainda que tacitamente. Como, no caso concreto, o casal não havia definido o regime matrimonial de bens, ter-se-ia acordado implicitamente em estabelecer como lei aplicável a do domićlío conjugal - no caso, a lei parisiense. ${ }^{16}$

A evolução do princípio, em nível internacional, não pode ser dissociada do avanço das relações de comércio para além dos limites estatais.

\footnotetext{
${ }^{14}$ Principles on Choice of Law in International Commercial Contracts. Aprovados em 19 de março de 2015. Disponível em: <https://www.hcch.net/pt/instruments/conventions/full-text/?cid=135> Acesso em: 03 jun. 2019.

${ }^{15}$ ARAUJO, Nádia de. Op. Cit., p. 376.

${ }^{16}$ CASTRO, Amilcar de. Direito internacional privado. Rio de Janeiro: Renovar, 2008, pp. 137-138.
} 
Deste modo, até o final do século XVIII não foram alcançados progressos expressivos quanto ao desenvolvimento do conceito e sua aplicação pelos tribunais.

Já no século XIX, surgiram questões relativas ao transporte marítimo que fizeram surgir conflitos judiciais onde a questão sobre a lei aplicável aos contratos era abordada. Antes disso, o entendimento predominante era o da regra do lex loci contractus, defendida pelo autor holandês Ulrich Huber, que foi citado em alguns dos primeiros casos sob jurisdição inglesa que versavam sobre conflito na escolha da lei aplicável, ainda na segunda metade do século XVIII. ${ }^{17}$

O jurista defendia que os contratos internacionais deveriam obedecer a lei do local de sua celebração, tanto no que diz respeito à forma, quanto ao teor do contrato. No entanto, interessa observar que tal aplicação não era absoluta, mesmo para Huber, que entendia que, quando a lei do local de celebração do contrato não permitia o exercício daquela prestação de serviço, ou o comércio do produto, isto deveria ser levado em consideração. ${ }^{18}$

Em outras palavras, Huber reconhecia que, mesmo sendo aplicável a lei do local de celebração, caso a lei do local de execução fizesse alguma objeção quanto ao objeto do contrato, tal impedimento deveria ser respeitado.

No entanto, apesar de a regra do lex loci contractus prevalecer, alguns autores reivindicavam a aplicação da lei do local de execução do contrato, como o americano Joseph Story.

\footnotetext{
${ }_{17}^{17}$ São os exemplos de Robinson v. Bland, julgado em 1760, e Holman v. Johnson, de 1775.

18 "However, it seems that this rule of the law of the place of contracting was not an absolute one. In his characteristically concise way, Huber gives an example of a contract for the sale of goods made in State A, where it is valid. If the parties intended the contract to be performed in State B, where the sale of the particular type of goods was prohibited, the contract would not be upheld. The normal principle of territoriality was under Huber's general approach to give way where it would prejudice the powers or rights of another State, here the State of performance with its prohibition of the sale in question." McCLEAN, David. De Conflictu Legum. Perspectives on private international law at the turn of the century. General Course on Private International Law, p. 130.
} 
Para o professor da Universidade de Harvard e membro da Suprema Corte ados Estados Unidos, faria sentido aplicar a um contrato internacional a legislação do local onde foi celebrado apenas se este coincidisse com o local de sua execução. ${ }^{19}$

Foi apenas na segunda metade do século XIX, que passaram a ser proferidas decisões tratando diretamente da escolha da lei aplicável, como o caso Lloyd v. Guibert ${ }^{20}$, na Inglaterra, além do caso Pritchard v. Norton ${ }^{21}$, nos Estados Unidos.

O primeiro envolvia um contrato celebrado em St. Thomas, que fazia parte das Índias Ocidentais Dinamarquesas, dispondo sobre o transporte de mercadorias do Haiti para Liverpool, na Inglaterra. O conflito versava sobre a aplicabilidade da lei dinamarquesa - do local da celebração - ou de lei escolhida pelo mútuo acordo entre as partes. A decisão, de 1865, firmou entendimento expresso no sentido de que a lei aplicável ao contrato é aquela escolhida pelas partes, ainda que tacitamente.

É interessante observar que os tribunais - como aconteceu no caso Lloyd - não necessariamente exigiam a manifestação expressa das partes (declaração de vontade) pela escolha da lei aplicável, reconhecendo o que seria a intenção dos contratantes (vontade interna do agente) como motivo suficiente para reconhecer a aplicação de uma determinada lei. ${ }^{22}$

No segundo caso, foi reconhecida a validade da manifestação da vontade das partes na definição da lei aplicável ao contrato. Em decisão da Suprema Corte Americana, proferida em 1882, foi firmado entendimento de

\footnotetext{
${ }^{19}$ McCLEAN, David. De Conflictu Legum. Op. Cit.. p. 131.

${ }^{20}$ Corte da Câmara do Erário Público (Court of Exchequer Chamber), LR 1 QB 115, 1865.

${ }^{21}$ Suprema Corte dos Estados Unidos, 106 US 124, 1882.

22 "Enquanto os componentes da teoria da vontade (Willenstheorie) entendem que se deve perquirir a vontade interna do agente, vontade real (Savigny, Windscheid, Dernburg, Unger, Oertmann, Enneccerus) de outro lado, os partidários da teoria de declaração (Erklarungstheorie) entendem que não se precisa cogitar do querer interior do agente, bastando deter-se na declaração (Zittelmann)." PEREIRA, Caio Mário da Silva. Op. cit. p. 402.
} 
que, apesar de a ação originária ter sido proposta perante o foro de Louisiana sendo a lex fori a do referido estado americano -, caberia a aplicação da lei do estado de Nova York a determinados aspectos contratuais, em respeito à intenção das partes contratantes.

A decisão do caso em pauta foi inovadora na medida em que diferenciou a lei aplicável ao procedimento e ao teor da matéria discutida. Neste sentido, estabeleceu que a lei que rege o contrato pode ser alienígena, porém, a lei do foro, que regulamenta o procedimento, deve ser a lei local. ${ }^{23}$

Essa mudança de entendimento dos tribunais encontrou inspiração na filosofia iluminista do "laissez faire ",24, que deu força à ascensão da autonomia da vontade para a escolha da lei aplicável aos contratos internacionais, como uma vertente da onda de liberalismo econômico cujo principal defensor fora Adam Smith.

Em 1910, na França, foi julgado o caso American Trading Co. em que se discutia se a lei aplicável ao contrato firmado entre a referida empresa e a transportadora Québec Steamship seria a lei americana - do local de celebração - ou a lei francesa.

A decisão se deu no sentido de que as partes haviam optado tacitamente pela escolha da lei francesa - devendo esta ser a lei aplicável -, tendo em vista que no contrato fora incluída cláusula de exoneração de responsabilidade que, enquanto proibida pela lei americana, era perfeitamente válida segundo o ordenamento jurídico francês.

\footnotetext{
23 "The principle is, that whatever relates merely to the remedy and constitutes part of the procedure is determined by the law of the forum, for matters of process must be uniform in the courts of the same country; but whatever goes to the substance of the obligation and affects the rights of the parties, as growing out of the contract itself, or inhering in it or attaching to it, is governed by the law of the contract." Disponível em: <https://h2o.law.harvard.edu/cases/3822>. Acesso em: 03 jun. 2019.

24 Segundo os pensamentos liberalistas, quanto menor a intervenção do Estado nas relações econômicas, mais elas teriam capacidade de se desenvolver. Isso se aplica ao âmbito dos contratos: se as partes pudessem escolher por si mesmas, conforme acordo de vontade entre elas estabelecido, não haveria motivo suficiente capaz de justificar a intervenção do Estado em tal escolha.
} 
No caso Vita Food Products, Inc. v. Unus Shipping Co. Ltd ${ }^{25}$,, do ano de 1939, foi proferida decisão emblemática em favor do princípio da autonomia da vontade em sentido amplo, tendo em vista que as partes haviam acordado, em sede contratual, que a legislação aplicável seria a lei inglesa, apesar de o contrato não ter nenhum elemento que o relacionasse à Inglaterra. A decisão afastou completamente, portanto, a regra da lei do local de celebração - que era a predominante desde a Idade Média até aquele momento - em respeito à escolha feita pelas partes. ${ }^{26}$

A relevância do caso se justifica pelo fato de a decisão - proferida pelo Comitê Judiciário do Conselho Privado na Apelação Cível 277, movida pela Vita Food Products, Inc, contra decisão emanada pela Suprema Corte da Nova Escócia - afirmou a primazia da intenção das partes na esfera contratual e a abrangência dessa liberdade no exercício de escolha da lei aplicável à relação contratual entre elas estabelecida.

Segundo David McClean, o caso Vita Food é importante por ter rejeitado a noção de que a liberdade das partes estaria limitada à escolha da lei aplicável segundo um leque de opções previamente determinado, com base no local de celebração e execução do contrato. ${ }^{27}$

Deste modo, ao reconhecer a legitimidade da escolha das partes pela aplicação da inglesa, que não guardava qualquer relação com o local da celebração ou execução das obrigações contratuais, a decisão revolucionou a visão tida até então sobre a autonomia das partes, conferindo a elas liberdade ainda maior para contratar.

\footnotetext{
${ }^{25}$ Judicial Committee of the Privy Council, AC 277, 1939.

26 "A decisão judicial determinou que uma escolha expressa de lei aplicável a um contrato deveria ser obedecida se o contrato fosse celebrado de boa fé e não se mostrasse contra a ordem pública." ARAÚJO, Nádia de. Op. Cit., p. 359.

27 "The especial importance of the Vita Food case lies in its rejection on the notion that the parties could choose from only a limited list of options, such as places of contracting and performance." McCLEAN, David. Op. Cit., p. 137-138.
} 
Já em 1953, a Suprema Corte Americana também estabeleceu, em Lauritzen v. Larsen $^{28}$, que aos contratos deveria ser aplicada a lei escolhida pelas partes contratantes. ${ }^{29}$

Nos Estados Unidos, portanto, passou-se a adotar uma posição jurisprudencial em favor do principio da autonomia da vontade das partes na escolha da lei aplicável aos contratos, principalmente pelo fato de cada estado da federação ter ordenamento jurídico próprio. A partir do momento que as partes estivessem aptas a escolher a lei aplicável à relação contratual entre elas estabelecida, menos frequentes seriam os casos de conflitos de leis que chegariam ao Poder Judiciário norte americano.

Na Inglaterra, o mesmo fenômeno pôde ser observado, graças ao seu desenvolvimento econômico. Nos tribunais ingleses, surgiu o conceito de "proper law of the contract", que seria a lei mais apropriada para reger um determinado contrato. As cortes inglesas entendiam que, para definir que lei seria essa, era possível recorrer à manifestação da vontade das partes nesse sentido - fosse ela expressa ou tácita. ${ }^{30}$

Deste modo, as teorias anteriormente predominantes - quais fossem, a do local de celebração do contrato, datada da Idade Média, e da lei do local de execução do contrato, defendida por Savigny ${ }^{31}$ - foram sendo superadas à

\footnotetext{
${ }^{28}$ Suprema Corte dos Estados Unidos, 345 U.S. 571, 1953.

29 "Except as forbidden by some public policy, the tendency of the law is to apply in contract matters the law which the parties intended to apply." Trecho da decisão proferida pela Suprema Corte Americana. Disponível em: 〈https://www.law.cornell.edu/supremecourt/text/345/571>. Acesso em 03 jun. 2019.

${ }_{30}^{30}$ McCLEAN, David. Op. Cit. p. 135.

31 "Savigny rejected, as accidental, transitory and lacking any substantial justification, the application of the law of the place of contracting. He favored the place of performance as the seat of the obligation, because the fulfillment of the obligation is that to which the whole expectation of the parties was directed. He uses language that speaks of the intention or choice of the parties, of their voluntary submission to a particular law, but the apparent similarity of language should not lead anyone to suppose that he was thinking in terms in any way equivalent to modern doctrines of party autonomy. He was simply saying that the law of the place of performance governs, and the place in question must be identified from the agreement of the parties. He develops a detailed theory as to how
} 
medida que a autonomia da vontade foi ganhando cada vez mais força na jurisprudência norte-americana e europeia.

Assim, as regras de conexão, anteriormente formuladas com base nas teorias supramencionadas, foram sendo substituídas por normas de DIPri protagonizadas pela autonomia da vontade das partes. ${ }^{32}$

A evolução que teve como pioneiros Estados Unidos e Inglaterra, seguidos por outros países europeus, ${ }^{33}$ não foi acompanhada no mesmo ritmo pelos países da América Latina, que demonstraram certa resistência em atualizar suas regras de conexão às tendências do cenário internacional.

Foi então que, pressionados pela necessidade de exercerem influência no comércio internacional, a Organização dos Estados Americanos (OEA) promoveu a V Conferência Interamericana sobre Direito Internacional Privado, no México, que culminou na Convenção Interamericana sobre direito aplicável aos contratos internacionais. ${ }^{34}$

A referida Convenção estabeleceu a possibilidade de escolha da lei aplicável aos contratos internacionais e, em caráter subsidiário, reconheceu a regra dos vínculos mais estreitos. No entanto, a Convenção foi ratificada apenas pelo México e Venezuela, não tendo sido capaz de atender a efetividade desejada quando da sua elaboração.

A Convenção das Nações Unidas para a Compra e Venda Internacional de Mercadorias (1980), por outro lado, ganhou cada vez mais adeptos com o

the place of performance is to be determined when it is not specified in the contract, with the domicile of the debtor as the final, safety-net rule." McCLEAN, David. Op. Cit., p. 129.

32 Dois exemplos são o Second Restatement americano (1971), que consagrou o princípio da proximidade (vínculos mais estreitos) e a Convenção sobre a lei aplicável às obrigações contratuais (1980), celebrada em Roma, que enalteceu o princípio da autonomia da vontade à escolha da lei aplicável aos contratos internacionais e, em caráter subsidiário, reconheceu a regra dos vínculos mais estreitos.

${ }^{33}$ França, Itália e Alemanha são alguns exemplos.

${ }^{34}$ CONVENÇÃO INTERAMERICANA SOBRE DIREITO APLICÁVEL AOS CONTRATOS INTERNACIONAIS. Disponível em: 〈http://www.oas.org/juridico/portuguese/treaties/b-56.htm〉. Acesso em: 03 jun. 2019. 
passar dos anos, inclusive na América Latina, o que será melhor abordado adiante.

Fato é que, com a chegada do século XX, pôde-se observar adesão cada vez mais ampla ao princípio da autonomia da vontade pelas Cortes de diversos países. A evolução da aceitação do princípio da autonomia das partes fez, inclusive, com que fosse considerado princípio fundamental do direito internacional privado, já que é ponto focal entre uma vasta gama de ordenamentos jurídicos domésticos ${ }^{35}$, por mais que as limitações dadas ao princípio variem de um Estado para outro. ${ }^{36}$

\subsection{O princípio no ordenamento jurídico brasileiro}

No ordenamento jurídico brasileiro, é o art. $9^{\circ}$ da Lei de Introdução às Normas do Direito Brasileiro (LINDB) ${ }^{37}$, transcrito abaixo, que estipula a regra geral para a definição da lei aplicável aos contratos internacionais:

Art. 9ำ Para qualificar e reger as obrigações, aplicar-se-á a lei do país em que se constituírem.

$\S 1^{\text {o }}$ Destinando-se a obrigação a ser executada no Brasil e dependendo de forma essencial, será esta observada, admitidas as peculiaridades da lei estrangeira quanto aos requisitos extrínsecos do ato.

$\S 2^{\mathrm{o}}$ A obrigação resultante do contrato reputa-se constituída no lugar em que residir o proponente.

O dispositivo acima destacado causa rebuliço na doutrina e jurisprudência brasileiras. Antes dele, vigorava o artigo 13 da Introdução ao

\footnotetext{
35 "The parties right to choose the law which governs an international contract is so widely accepted by the countries of the world that it belongs to the common core of the legal systems."

LANDO, Ole. The conflict of laws of contracts: general principles. Recueil des Cours, v. 189, 19984VI, p. 237.

36 "Atualmente, o princípio da autonomia da vontade é universalmente aceito, com adoção expressa tanto em convenções internacionais como na legislação interna de diversos países." ARAÚJO, Nádia de. Op. cit.

${ }^{37}$ Decreto-Lei $N^{\circ}$ 4.657, de 4 de setembro de 1942. Á época de sua edição denominada Lei de Introdução ao Código Civil, de 1942.
} 
Código Civil de 1916, que enaltecia o princípio da autonomia da vontade mesmo que de maneira indireta -, ao dispor que "regulará, salvo disposição em contrário, quanto à substância e aos efeitos das obrigações, a lei do lugar onde foram contraídas". ${ }^{38}$

Segundo essa redação, as partes contratantes podiam estabelecer como lei aplicável aos direitos e obrigações entre elas assumidas, lei diversa daquela onde as obrigações foram contraídas.

A substituição da norma que dava respaldo à escolha da lei aplicável aos contratos internacionais pelas partes, pelo artigo $9^{\circ}$ supramencionado é alvo de duras críticas, em virtude do retrocesso que foi capaz de gerar às relações de comércio internacional vinculadas de alguma forma ao Brasil, reféns do "custo Brasil", conforme definido por Nádia de Araújo. ${ }^{39}$

Oscar Tenório afirma não ter sido a autonomia da vontade proibida expressamente pela LINDB, apesar de a supressão da expressão "salvo disposição em contrário" não ter sido feita ao acaso. O que Tenório busca defender é, portanto, que o princípio da autonomia da vontade para escolha da lei aplicável será válido quando a lei do local de celebração do contrato assim permitir. Sendo assim, defende que a LINDB permite a aplicação indireta do princípio. ${ }^{40}$

\footnotetext{
38 "Bevilaqua enunciou a lex contractus como sendo a lei do local da celebração, salvo estipulação em contrário, ou quando ofensiva ao direito nacional dos contratantes ou à ordem pública." BEVILAQUA, Clóvis. Op. cit. In: ARAÚJO, Nádia de. Op. cit.

39 "A situação é especialmente crítica no Brasil, pois conforme dito no começo deste artigo, o país ainda utiliza o critério da época medieval do local da celebração. (...) Essa situação que distancia a legislação interna brasileira das regras adotadas pelos parceiros comerciais do país, em especial Estados Unidos e países europeus, adicionam elementos negativos ao chamado custo Brasil, o custo adicional que as operações com o país suportam em face da dificuldade de optar pela legislação mais adequada ao desejo das partes contratantes.” ARAUJO, Nádia de. Uma visão econômica do Direito Internacional Privado: contratos internacionais e autonomia da vontade. In: Luciano Benetti Timm. (Org.). Direito e economia no Brasil. 1. ed. São Paulo: Atlas, 2014, p. 433-444.

${ }^{40}$ TENORIO, Oscar. Lei de Introdução ao Código Civil brasileiro. Rio de Janeiro: Editor Borsoi, 1955.
} 
Um terceiro entendimento doutrinário possível é o defendido por Jacob Dolinger, que afirma que o artigo $9^{\circ}$ deve ser interpretado de forma teleológica, considerando-se a realidade das relações jurídicas internacionais contemporâneas, bem como o panorama do Direito Internacional Privado atual e os interesses da economia brasileira, em crescente internacionalização, sem prejuízo da necessidade de se ter em mente o dispositivo revogado, que fazia menção à escolha da lei aplicável pelas partes. ${ }^{41}$

A posição defendida por Dolinger não é, no entanto, a que predomina na doutrina brasileira atualmente, sendo certo que muitos dos estudiosos de Direito Internacional Privado reconhecem que não há, atualmente, autorização concreta para a escolha da lei aplicável aos contratos internacionais na LINDB.

Esses doutrinadores acreditam que a retirada do trecho "salvo disposição em contrário" não se deu por acaso, mas pela verdadeira intenção do legislador de restringir a autonomia privada no âmbito dos contratos internacionais. $^{42}$

Não obstante o aparente caos que se instaura quanto à interpretação do artigo $9^{\circ}$ da LINDB, o ordenamento jurídico brasileiro traz certos elementos que consagram o princípio da autonomia da vontade em casos específicos, como a da Lei no 9.307/1996 (Lei de Arbitragem) e o Decreto n ${ }^{\circ}$ 8.327/2014, que internalizou a Convenção das Nações Unidas sobre Contratos de Compra e Venda Internacional de Mercadorias ao sistema jurídico pátrio ${ }^{43}$ - que será visto com mais detalhes adiante, tendo em vista que se trata do principal aspecto que se busca abordar no presente trabalho.

${ }^{41}$ DOLINGER, Jacob. A livre escolha pelas partes da lei aplicável nos contratos internacionais. Revista de Direito do Estado, Rio de Janeiro, Renovar, n 2, 2006, p. 243.

${ }^{42}$ Nesse sentido, faz-se referência à Maria Helena Diniz, Nádia de Araújo e João Grandino Rodas.

43 "A CISG passou a integrar o direito positivo brasileiro, contribuindo para de certa forma reduzir o problema relativo à lei aplicável, já que a sua determinação será irrelevante nas situações em que a convenção for utilizada." BASEDOW, Jurgen. Towards a universal doctrine of breach of contract: the impact of the CISG. International Review of Law and Economics, v. 25, p. 487-500, 2005. In: ARAÚJO, Nádia de. Op. cit. 
A Lei de Arbitragem, por sua vez, em seu art. $2^{\circ}$, prestigiou a autonomia das partes, ao conferir aos contratantes ampla liberdade de escolha das normas aplicáveis tanto ao procedimento arbitral, quanto ao fundo da causa. ${ }^{44}$

${ }^{44}$ ARAÚJO, Nádia de. Op. cit. 


\section{CAPÍTULO 2- A CONVENÇÃO DAS NAÇÕES UNIDAS SOBRE CONTRATOS DE COMPRA E VENDA INTERNACIONAL DE MERCADORIAS (CISG)}

\subsection{Aspectos gerais}

A Convenção das Nações Unidas sobre Contratos de Compra e Venda Internacional de Mercadorias (CISG) ${ }^{45}$, também conhecida como Convenção de Viena, surge em um contexto histórico de intensificação acelerada do comércio internacional àquela época, fruto de uma série de fatores.

Dentre eles, destacam-se a preocupação da comunidade internacional com o desenvolvimento dos Estados menos desenvolvidos e estabelecimento de uma ordem econômica internacional mais solidária; o incremento de avanços tecnológicos, que viabilizaram progressos significativos, especialmente nos segmentos de transporte e comunicação, capazes de quebrar barreiras territoriais entre os Estados, o que intensificou as relações comerciais entre eles e, com isso, sua interdependência econômica.

Neste sentido, a globalização - fenômeno caracterizado pela circulação, em nível internacional, de recursos, pessoas e serviços, produto do aumento das interações entre agentes estatais e privados - fez crescer a passos largos as

\footnotetext{
${ }^{45}$ Aprovada em Conferência realizada em Viena, no ano de 1980, como melhor se verá adiante, a CISG foi internalizada pelo Brasil apenas em 2014, através do Decreto ${ }^{\circ} 8.327$ de 16 de outubro de 2014. Apesar de ter participado ativamente das discussões durante a Conferência Diplomática, que resultaram na aprovação do texto final (Documento A/CONF.97/18), o país tardou em integrar a Convenção ao seu ordenamento jurídico. Neste sentido, cabe apontar: "Tradicionalmente o Estado brasileiro é isolacionista, voltado para si mesmo. Como todos os grandes países, ou países-baleias, o Brasil tem o complexo da auto-suficiência. [...] Por essa razão, a preocupação com o direito internacional sempre foi pequena". BAPTISTA, Luiz Olavo. Contratos internacionais da administração pública: novos rumos?. In: MELLO, Celso Antônio Bandeira de (Org.). Estudos em homenagem à Geraldo Ataliba. São Paulo: Malheiros, v. 2, 1997, p. 450.
} 
transações internacionais e, com isso, surgiu a necessidade de regulamentá-las a nível global. ${ }^{46}$

Iniciativa da Comissão das Nações Unidas para o Comércio Internacional (UNCITRAL), ${ }^{47}$ desde o início de seus trabalhos, a CISG foi concebida com o objetivo de proporcionar um regime moderno, uniforme e justo, aplicável aos contratos de compra e venda de mercadorias celebrados em âmbito internacional, uma vez que essa espécie contratual é considerada a espinha dorsal das relações de comércio internacional. ${ }^{48}$

Posto isto, a Convenção contribuiria de maneira significativa na ampliação da segurança jurídica conferida a esses contratos e, ademais disso, seria capaz de reduzir os custos envolvidos nas transações por eles formalizadas.

Vale frisar que, quando da elaboração do texto normativo, aprovado em 1980, a UNCITRAL preocupou-se em alcançar um texto equilibrado - que atendesse aos interesses tanto do comprador quanto do vendedor -, flexível e de fácil entendimento, fatores que se revelaram essenciais para a sua aceitação pelos Estados signatários. ${ }^{49}$

\footnotetext{
46 "Segundo FAUVARQUE-COSSON a internacionalização do Direito seria fenômeno relacionado à globalização. Ela seria incentivada pelo incremento da mobilidade dos indivíduos, a criação de organizações internacionais e suas atividades. A questão chave que surgiria, portanto, seria qual a consequência desse fenômeno para os diferentes sistemas legais nacionais, desafio posto, principalmente, pela multiplicação das fontes normativas, nacionais, internacionais, privadas e públicas." FAUVARQUE-COSSON, Bénédicte. Towards a Renewed Universalism in Law, In: Diogenes, n. 219. SAGE, 2008, p. 56. In: GLITZ, E. Z. Frederico. Contrato, globalização e lex mercatória. Convenção de Viena 1980 (CISG), Princípios Contratuais UNIDROIT (2010) e INCOTERMS (2010). São Paulo: Editora Clássica, 2014, p. 61.

${ }^{47}$ A UNCITRAL foi criada pela Organização das Nações Unidas (ONU), através da Resolução 2205 (XXI), de 17 de Dezembro de 1966, com o objetivo de desempenhar papel relevante no desenvolvimento de um regime jurídico moderno e uniforme, capaz de facilitar o comércio internacional, considerando-se o crescimento da interdependência econômica entre os Estados. Disponível em <https://uncitral.un.org/>. Acesso em: 15 abr. 2019.

48 "The contract of sale of goods is the backbone of international trade in all countries, irrespective of their legal tradition or level of economic development. The CISG is therefore considered one of the core international trade law conventions whose universal adoption is desirable." Disponível em <https://uncitral.un.org/en/texts/salegoods/conventions/sale_of_goods/cisg>. Acesso em: 15 abr. 2019.

${ }^{49}$ A necessidade de elaboração da CISG surgiu em virtude da falta de êxito de legislações que apareceram antes dela - quais sejam, a Lei uniforme sobre o contrato de compra e venda internacional
} 
O resultado desse esforço foi a ampla adesão à CISG, que, até junho de 2019, conta com 89 Estados signatários.

\subsection{Estrutura}

A Convenção é composta por um preâmbulo - que leva em consideração seus princípios norteadores e o objetivo perseguido quando da sua elaboração, contextualizando a lei -, seguido de quatro "Partes" que tratam, respectivamente, da esfera de aplicação da CISG, formação do contrato, venda de mercadorias e das provisões finais, que incluem normas de Direito Internacional Público. ${ }^{50}$

\subsubsection{Preâmbulo}

O preâmbulo, como é de sua natureza, apresenta o contexto que inspirou a edição da norma. Nele, resta evidente a preocupação da UNCITRAL com a Nova Ordem Econômica Internacional ${ }^{51}$, de modo a assegurar a elaboração de uma Convenção pautada em valores que reflitam a igualdade e benefício

de bens móveis e a Lei uniforme sobre a formação de contratos de compra e venda internacional de bens móveis, ambas aprovadas em conferência realizada na Haia, em 1964. Por esse motivo, a UNCITRAL se propôs a revisar as matérias por elas abordadas e verificou que seria necessária a concepção de uma nova lei. Iniciaram-se, então, os trabalhos para a sua elaboração, que resultaram em diversos projetos. A CISG originou-se do último projeto apresentado, por ocasião da Conferência celebrada em Viena, no ano de 1980, na qual foi aprovada por unanimidade. FERRARI, Franco. $L a$ Compra e Venta Internacional. Aplicabilidad y aplicaciones de la Convención de Viena de 1980. Valencia: Tirant lo Blanch, 1999, p. 24.

${ }^{50}$ Artigos 89 a 101, CISG.

${ }^{51} \mathrm{O}$ preâmbulo faz referência à Declaration on the Establishment of a New International Economic Order (Resolução 3201 de 01/05/1974) e ao Programme of Action on the Establishment of a New International Economic Order of 1 May 1974 (Resolução 3202 de 01/05/1974), ambos da ONU. O principal objetivo dos referidos documentos é estabelecer diretrizes aos órgãos e organizações do sistema das Nações Unidas para alcançar uma nova ordem econômica internacional, onde os países em desenvolvimento tenham capacidade de efetivamente exercer seu direito de se desenvolver. Neste ponto, destaca-se o reconhecimento da comunidade internacional em relação ao dever de solidariedade que os países industrializados deveriam ter com os países menos desenvolvidos. 
mútuo dos Estados signatários, capazes de promover a manutenção de relações amigáveis entre eles.

Ademais disso, destaca a importância da adoção de leis uniformes aplicáveis aos contratos de compra e venda internacional de mercadorias para promover a remoção das barreiras legais impostas ao comércio internacional, impulsionando o seu desenvolvimento. As referidas normas devem, ainda, levar em consideração os diferentes sistemas sociais, econômicos e legais existentes para alcançar esse objetivo.

\subsection{2 Âmbito de aplicação}

A Parte I é responsável por trazer as disposições referentes à "Esfera de Aplicação" da CISG.

Em relação a esse tema, é relevante saber que a Convenção é aplicável somente aos contratos internacionais de compra e venda de mercadorias, o que lhe atribui caráter de lei específica.

Restam excluídos, portanto, contratos que dispõem sobre prestação de serviços. Além disso, faz-se algumas ressalvas quanto a determinados tipos de mercadoria, como as destinadas a uso pessoal, familiar ou doméstico ${ }^{52}$, adquiridas em leilão ou em processo executivo. ${ }^{53}$ A Convenção de Viena

\footnotetext{
${ }^{52}$ Aqui, importa frisar que os consumidores estão excluídos do âmbito de aplicação da CISG. “... [o consumidor é ] considerado como parte mais fraca em uma contratação com um fornecedor, razão pela qual as principais codificações e convenções internacionais sobre o tema excepcionem essa categoria da norma que permite a autonomia da vontade." ARAUJO, Nádia de. Op. Cit., p. 433-444.

53 "Também estão excluídos do âmbito de aplicação da Convenção: invenções industriais, licenças, marcas e nomes comerciais, know how." AGUIAR JÚNIOR, Ruy Rosado de. Aspectos da Convenção de Viena sobre a compra e venda internacional de mercadorias (CISG) - 1980. Texto básico da palestra Resolução e adimplemento substancial na CISG, proferida em Curitiba, em 20 de março de 2014, durante o Congresso Internacional "A CISG e o Brasil”, no Auditório da Seção Judiciária do Paraná da Justiça Federal, realizado pelo Centro de Arbitragem e Mediação da Câmara de Comércio Brasil-Canadá (CAM-CCBC) e pela Escola da Magistratura do TRF da 4a Região (EMAGIS), em 19 e 20 de março de 2014.
} 
tampouco é aplicável ao comércio de valores mobiliários, títulos de crédito e moeda, navios, barcos, hovercraft, aeronaves e eletricidade. ${ }^{54}$

Seu artigo $1^{\circ}$ dispõe que a Convenção é aplicável aos contratos internacionais de compra e venda de mercadorias. O critério adotado pela Convenção para identificação desse caráter internacional dos contratos de compra e venda foi o da disposição territorial do estabelecimento das partes contratantes.

Deste modo, o primeiro passo para se identificar se a CISG será ou não aplicável ao contrato é verificar se as partes têm seus respectivos estabelecimentos em Estados diferentes. Por conta disso, é de se inferir que o conceito de "estabelecimento" seja importante na determinação do caráter internacional do contrato, para os fins da Convenção.

No entanto, a CISG não traz essa definição, limitando-se a estipular orientações gerais, aplicáveis aos casos em que (i) uma das partes tenha mais de um estabelecimento ou (ii) uma das partes não tenha estabelecimento. ${ }^{55}$

No primeiro caso, o estabelecimento será considerado como sendo o local com relação mais próxima ao escopo do contrato e a sua execução, levando-se em consideração, para isso, circunstâncias envolvidas tanto no momento da negociação quanto da conclusão das obrigações contratuais. Na segunda hipótese, a referência será a residência habitual da parte.

Uma vez identificado o caráter internacional da relação contratual, deve-se observar, ainda, outros critérios de aplicabilidade da CISG.

$\mathrm{O}$ art. $1^{\mathrm{o}}$ especifica que a Convenção é aplicável quando os estabelecimentos das partes estão localizados em Estados Contratantes ${ }^{56}$, o que se denomina aplicação direta; ou, ainda, quando as regras de Direito

\footnotetext{
${ }^{54}$ Art. 2 , CISG.

${ }_{55}^{55}$ Art. 10, CISG.

${ }^{56}$ Estado Contratante é o Estado signatário, que aderiu à CISG, integrando-a ao ordenamento jurídico doméstico.
} 
Internacional Privado levem à aplicação da lei de um Estado Contratante, que a doutrina chama de aplicação indireta da Convenção ${ }^{57}$.

Um exemplo dessa segunda hipótese, abordada abstratamente pela Convenção, seria: imagine-se um contrato de compra e venda de mercadorias celebrado entre uma parte com estabelecimento no Brasil e a outra na França, em momento anterior à ratificação da Convenção pelo Estado brasileiro, sendo certo que a celebração do contrato se deu na França.

Nesse caso, as regras de DIPri - mais precisamente o art. $9^{\circ}$ da LINDB ${ }^{58}$ -levariam à aplicação da lei francesa e, consequentemente, da CISG, que já havia sido ratificada pelo Estado francês em 1982, mesmo que a CISG ainda não tivesse sido adotada pelo Brasil. ${ }^{59}$

Ainda quanto à esfera de aplicação da CISG, faz-se necessário abordar o artigo $6^{\circ}$, que estabelece que as partes poderão excluir a sua aplicação, no todo ou em parte. O referido dispositivo possibilita às partes, ainda, estipular efeitos distintos daqueles previstos na Convenção. Por esse artigo verifica-se que as partes têm autonomia inclusive para excluir a CISG de aplicação ao seu contrato internacional, se assim o desejarem.

\footnotetext{
${ }^{57}$ Quanto à aplicação indireta da CISG, consagrada no seu artigo 1 (b), é importante notar que sua aplicabilidade pode ser afastada pelo Estado Contratante, conforme dispõe o artigo 95 da Convenção. Nesta perspectiva: "Nevertheless, the indirect application is conditional to the nonexistence of the declaration by the contracting State as mentioned in Article 95 of the CISG, which gives States the power not to be bound by the Article 1.1.b) rules." FERRARI, Franco. The CISG and its Impact on National Legal Systems. Munich: Editora sellier. European law publishers GmbH, 2008, p. 12.

${ }^{58}$ Art. $9^{\circ}$. Para qualificar e reger as obrigações, aplicar-se-á a lei do país em que se constituírem. $\S 1^{\circ}$ Destinando-se a obrigação a ser executada no Brasil e dependendo de forma essencial, será esta observada, admitidas as peculiaridades da lei estrangeira quanto aos requisitos extrínsecos do ato.§ $2^{\circ}$ A obrigação resultante do contrato reputa-se constituída no lugar em que residir o proponente.

59 "Se for designada a lei da França, Estado contratante, a Convenção será aplicada e não as regras do Código Civil Fr., como direito aplicável a essas relações internacionais, uma vez que os dispositivos materiais da Convenção se tornaram parte integrante do direito comum do Estado que a adotou." AYMONE, Priscila Knoll. A regulação do mérito da arbitragem mediante a utilização das regras internacionais de comércio: uma possibilidade decorrente da Lei Brasileira de Arbitragem e um paradoxo frente à LICC/42? In: FRADERA, Véra Maria Jacob de; MOSER, Luiz Gustavo Meira (Org.). A compra e venda internacional de mercadorias: estudos sobre a Convenção de Viena de 1980. São Paulo: Atlas, 2011.p. 62.
} 
Através dessas previsões, concentradas no artigo supramencionado, a CISG consagra o princípio da autonomia da vontade no âmbito das contratações internacionais, como veremos adiante.

\subsubsection{Princípios e disposições relevantes}

Outro aspecto importante sobre a CISG que merece ser abordado é a relevância dada aos seus princípios norteadores, que se encontram nos primeiros artigos da convenção (artigo 1 a 7).

Da leitura da Convenção, percebe-se que muitas de suas disposições foram pautadas em princípios - como, por exemplo, o da boa-fé objetiva e o da autonomia da vontade, já mencionado - do que a elaboração de um conjunto de regras de detalhamento extremamente aguçado.

$\mathrm{O}$ artigo $7^{\circ}$ da Convenção, inclusive, dispõe sobre a metodologia que deve ser utilizada diante de alguma lacuna ${ }^{60}$. Nesse caso, fica estipulado que se deve recorrer aos princípios. Importa ressaltar que os referidos princípios devem ser extraídos do próprio texto da Convenção, e não dos ordenamentos jurídicos domésticos dos Estados contratantes, pois isso quebraria o caráter internacional e uniforme que se buscou quando a CISG foi editada.

É correto afirmar que o princípio da boa-fé, de observância obrigatória no comércio internacional, está previsto expressamente apenas no art. $7^{\circ}$. No entanto, ele se faz implicitamente presente em inúmeros outros dispositivos, que trazem algumas das disposições de maior relevância na Convenção.

\footnotetext{
60 "Lacunas internas resultam do fato de a Convenção regular a matéria, mas não de modo suficiente. Para supri-las, recorre-se aos princípios gerais da Convenção (art. 7); na falta desses princípios, buscase a lei aplicável, conforme o Direito Internacional Privado." JÚNIOR, Ruy Rosado de Aguiar. Op. cit.
} 
O artigo 16, por exemplo, preconiza que uma proposta não poderá ser revogada se for razoável que o seu destinatário a considere irrevogável e tenha agido em confiança à proposta recebida. ${ }^{61}$

Enquanto isso, o artigo 21 trata da aceitação tardia da proposta em decorrência de atraso alheio à vontade do destinatário da mesma. Fica definido que, caso haja atraso na entrega do aceite, mas tendo este sido expedido em prazo que seria - ao menos teoricamente - plausível para a sua chegada caso não houvesse nenhuma irregularidade, esse aceite terá efetividade como se o prazo tivesse sido respeitado. ${ }^{62}$

Além desses, os artigos 37 e 46 também fazem alusão ao princípio da boa-fé, trazendo disposições sobre a responsabilidade do vendedor para com as mercadorias, bem como sobre o seu direito-dever de sanar eventuais desconformidades existentes no que diz respeito ao que fora pactuado contratualmente, e às condições das mercadorias entregues.

Os artigos 85 a 88 da Convenção tratam, ainda, da obrigação das partes de preservar as mercadorias. A intenção dos referidos dispositivos foi de trazer respaldo legal às situações nas quais as partes encontram-se, justificadamente, em posse ou controle de bens que deveriam estar sob o controle da parte contrária.

Nessas situações, fala-se na obrigatoriedade de preservação do bem, em contrapartida ao dever da outra parte de restituir os gastos despendidos na manutenção do mesmo. Busca-se, mais uma vez, preservar a boa fé na condução da relação contratual entre as partes. ${ }^{63}$

\footnotetext{
${ }^{61}$ Art. 16 (2), b, CISG.

${ }^{62}$ Art. 21 (2), CISG.

${ }^{63}$ Outros exemplos de dispositivos relacionados diretamente ao princípio da boa fé seriam: artigo 29 (2), 40, 47 (2), 64 (2) e 84, CISG.
} 


\subsection{Autonomia da vontade na CISG}

Conforme já mencionado, a CISG consagra seu respeito à autonomia da vontade das partes contratantes no seu art. $6^{\circ}$, que permite a elas derrogar a aplicação da Convenção no seu todo ou apenas em parte, ao que se soma a possibilidade de modificação de seus efeitos. ${ }^{64}$

Deste modo, mesmo que haja manifestação da vontade estatal no sentido de vincular-se à Convenção, a sua aplicação não é obrigatória para as partes que estabelecem entre si relação contratual de DIPri. Consagrado, portanto, o direito ao opt out. ${ }^{65}$

Segundo Franco Ferrari, ao permitir que as partes excluam a Convenção ou mitiguem suas provisões, seus elaboradores reafirmam o princípio de que a fonte primária aplicável aos contratos de comércio internacional é a autonomia da vontade - que já havia sido consagrado na Conferência da Haia de Direito Internacional Privado, em 1964, quando da aprovação da Lei uniforme sobre compra e venda internacional. ${ }^{66}$

Assim, resta inabalável o reconhecimento do caráter não mandatório da Convenção, bem como do papel central desempenhado pela autonomia da vontade no comércio internacional e, mais especificamente, na compra e venda internacional de mercadorias.

\footnotetext{
${ }^{64}$ NALIN, Paulo. STEINER, C. Renata. Compra e venda internacional de mercadorias. A Convenção das Nações Unidas sobre compra e venda internacional de mercadorias. Belo Horizonte: Editora Forum, 2016. p. 67.

65 "Because the CISG has adopted the 'opting out' system, its application is automatic. The CISG's application automatically arises when the conditions stated in Article 1 are satisfied. However, the Convention will not be applied if the parties totally or partially exclude its application, or if they modify its effects." C. Witz, L'exclusion de la Convention des Nations Unies sur le contrats de vente internationale de merchandises par la volonté des parties (Convention de Vienne du 11 avril 1980), In: Recueil Dalloz Sirey 17 (1990), p. 107-112. In: FERRARI, Franco. The CISG and its Impact on National Legal Systems. Munich: Editora sellier. European law publishers GmbH, 2008, p. 11.

${ }^{66}$ FERRARI, Franco. What Sources of Law for Contracts for the International Sale of Goods? Why One has to Look Beyond the CISG. Verona: International Review of Law and Economics, 2005, p. 331.
} 
Neste ponto, é necessário abordar a diferença entre a escolha pela não aplicabilidade da Convenção como um todo, ou seja, o exercício do opt-out ${ }^{67}$, e a opção pelo afastamento de algumas de suas disposições, ou, ainda, da mudança de alguns de seus efeitos.

Enquanto, no primeiro cenário, não há limitações ao exercício do direito conferido pela Convenção, no segundo existem algumas restrições aplicáveis, que merecem ser abordadas.

O artigo 96 da CISG dispõe que quando uma das partes tiver estabelecimento em Estado cuja legislação exija forma escrita de contratação e o referido Estado fizer a declaração prevista no artigo 12, não serão aplicadas as disposições dos artigos 11 e 29, ou da Parte II da CISG, que permitam manifestações de vontade das partes por forma diferente da escrita. ${ }^{68}$

Neste ponto, Ferrari alerta que existem visões distintas na doutrina e jurisprudência quanto aos efeitos do artigo 96. Destaca que uma das interpretações sugere que, caso uma das partes tenha estabelecimento em Estado aderente à reserva do artigo 96, o contrato deve ser elaborado ou modificado para a forma escrita.

Outra posição adotada seria a de que o simples fato de uma das partes se encaixar na situação narrada não seria suficiente para condicionar o contrato à forma exigida pelo Estado. Ao invés disso, deve-se recorrer às regras de direito

\footnotetext{
${ }^{67}$ “... é permitido às partes contratar a exclusão da CISG (ou seja, deixar de aplica-la a casos em que, naturalmente, seria aplicada), o que é chamado de opt-out. Tal escolha, de uma forma geral, parece ser contraproducente aos seus próprios interesses, uma vez que as priva da aplicação de uma lei que é reciprocamente conhecida, optando-se, por outro lado, pela incerteza de um direito local, muitas vezes escolhido a posteriori pelo juiz ou árbitro (ainda que por aplicação de regras previamente conhecidas). Naturalmente que, neste contexto, pode se sobressair o poder de negociação do contratante, o qual deseja impor à contraparte o seu direito nacional e a sua jurisdição." NALIN, Paulo. STEINER, C. Renata. Op. Cit., p. 69.

${ }^{68}$ Art. 96. O Estado Contratante cuja legislação exigir que os contratos de compra e venda sejam concluídos ou provados por escrito poderá, a qualquer momento, fazer a declaração prevista no artigo 12, no sentido de que, caso qualquer das partes tenha seu estabelecimento comercial nesse Estado, não se aplicarão as disposições dos artigos 11 e 29, ou da Parte II da presente Convenção, que permitirem a conclusão, modificação ou resolução do contrato de compra e venda, ou a proposta, aceitação ou qualquer outra manifestação de intenção por qualquer forma que não a escrita.
} 
internacional privado: caso estas indiquem a aplicabilidade da lei de Estado cuja reserva do artigo 96 tenha sido feita, o requisito formal seria cabível. Caso as normas de DIPri indiquem a incidência da lei de um Estado que não tenha feito essa reserva, a forma do contrato seguiria os critérios estabelecidos no artigo 11 da CISG - incidiria, portanto, o princípio da liberdade quanto à forma de contratação ("principle of freedom from form"). ${ }^{69}$

À exceção da hipótese acima destacada, a Convenção não limita expressamente o direito das partes contratantes de renunciar parcialmente a sua aplicação ou de modificar o teor de quaisquer outras de suas disposições, sendo certo que dispõem de ampla autonomia.

Importa esclarecer, contudo, que apesar de não expressamente definido pela Convenção, as partes não podem dispor sobre as provisões de direito internacional público, encontradas nos artigos 89 a 101, já que se trata de provisões direcionadas aos Estados contratantes e não às partes privadas.

Além do opt-out, que, como já visto, é consagrado pela CISG, a autonomia da vontade também é assegurada através do direito ao opt-in. Neste sentido, é possível que as partes optem estrategicamente pela aplicabilidade da lei de um Estado Contratante, na intenção de fazer da CISG parte da lei aplicável, como integrante do ordenamento jurídico doméstico daquele Estado. $^{70}$

Sendo assim, o artigo 1 (b) da CISG confere respaldo jurídico à situação onde partes de Estados não contratantes elegem a CISG como lei aplicável a partir da escolha do ordenamento jurídico de um Estado signatário. Demonstrada, portanto, mais uma vez, a importância conferida à autonomia das partes no texto da Convenção.

\footnotetext{
${ }^{69}$ FERRARI, Franco. Op. Cit., p. 333.

${ }^{70}$ SPAGNOLO, Lisa. A glimpse through the kaleidoscope: choices of law and the CISG (Kaleidoscope Part I). SSRN. Disponível em: <https://papers.ssrn.com/sol3/papers.cfm?abstract_id=1514130>. Acesso em: 15 abr. 2019.
} 


\section{CAPÍTULO 3 - ESTUDO DE CASOS}

Criando ou não Direito novo, com base nas normas vigentes, o certo é que a jurisdição é uma das forças determinantes da experiência jurídica (...). Pode mesmo dizer-se que o seu alcance aumenta dia a dia, como decorrência da pletora legislativa e pela necessidade de ajustar as normas legais cada vez mais genéricas ou tipológicas, como modelos normativos abertos (standards) às peculiaridades das relações sociais.

Miguel Reale ${ }^{71}$

Estudar o princípio da autonomia da vontade na CISG sob a perspectiva de casos concretos é importante, pois a jurisprudência das cortes de jurisdições diferentes se mostra essencial - não só em países da common law - na unificação de entendimentos sobre conflitos relacionados à escolha de lei aplicável, que muitas vezes não são solucionados pelos ordenamentos jurídicos internos dos Estados. $^{72}$

Tendo isso em vista, passa-se a estudar casos concretos, provenientes de diversas jurisdições, que versam sobre a aplicabilidade da Convenção.

Como fonte de pesquisa, foram utilizadas as ferramentas de busca disponibilizadas na página na rede mundial de computadores da UNCITRAL, bem como da Universidade de Pace (Nova York, Estados Unidos). ${ }^{73}$

\subsection{Casos nos quais foi reconhecida a aplicação da CISG}

Conforme já abordado, de acordo com o artigo 6 da Convenção, as partes podem excluir sua aplicação, total ou parcialmente, ou derrogar suas provisões. Dito isso, é importante esclarecer o posicionamento dos tribunais em relação à aplicabilidade da CISG.

\footnotetext{
${ }^{71}$ REALE, Miguel. Lições preliminares de Direito. São Paulo: Saraiva, 2002, p.169.

${ }^{72}$ KAHN-FREUND, O. Op. Cit., p. 257.

${ }^{73}$ Case Law on UNCITRAL Texts. Disponível em: <https://www.uncitral.org/clout/> Acesso em: 15 abr. 2019. Search Cases in the CISG Database. Disponível em: <https://iicl.law.pace.edu/cisg/search/cases> Acesso em: 15 abr. 2019.
} 
O que pode ser observado na jurisprudência envolvendo o tema é que o juízo, antes de considerar a aplicação da referida norma ao caso concreto, avalia se houve manifestação de vontade das partes no sentido de não aplica-la - mesmo que a Convenção fosse, ao menos em um primeiro momento, aplicável àquela situação.

Com isso, cria-se uma condição para a aplicação da CISG, qual seja: a falta de manifestação da vontade das partes no sentido de não aplica-la. ${ }^{74}$ Portanto, para aplicar ou não a CISG aos casos concretos, os tribunais devem analisar se houve manifestação inequívoca das partes pelo opt out.

Em decisão proferida nos Estados Unidos em 2007, no caso The Travelers Property Casualty Company of America ("Travelers") and Hellmuth Obata \& Kassabaum, Inc. ("HOK”) v. Saint-Gobain Technical Fabrics Canada Limited ("Saint-Gobain") ${ }^{75}$, a Corte Distrital do estado de Minnesota entendeu que a Convenção de Viena de 1980 era aplicável ao contrato firmado entre as partes, já que esta não havia sido expressamente excluída por elas no instrumento contratual. ${ }^{76}$

No referido caso, as partes haviam previsto contratualmente cláusula de choice of law que determinava que os direitos e obrigações constantes do contrato seriam regulamentados pela lei do estado de Minnesota.

No curso do processo perante a Corte Distrital de Minnesota, os autores - Travelers e HOK - arguiram que a CISG era aplicável ao caso, enquanto a

\footnotetext{
74 "Thus, even if the Convention would otherwise be applicable, courts must determine that the parties have not excluded the Convention nor derogated from its provisions, thus elevating the lack of an exclusion to an applicability requirement of the Convention." Disponível em: <https://www.uncitral.org/pdf/english/clout/CISG-digest-2012-e.pdf>. Acesso em: 20 mai. 2019.

${ }^{75}$ United States District Court, District of Minnesota. The Travelers Property Casualty Company of America and Hellmuth Obata \& Kassabaum, Inc., Plaintiffs, v. Saint-Gobain Technical Canada Limted, formerly known as Bay Mills, Defendant. Civil No. 04-4386 ADM/AJB. 31 January 2007. Disponível em: <http://www.unilex.info/cisg/case/1166> Acesso em: 20 mai. 2019.

${ }^{76}$ Tratava-se de contrato de compra e venda internacional de materiais de construção firmado entre as partes já mencionadas. Os autores ajuizaram a demanda alegando que a Saint-Global havia entregado produtos com defeito e, por conta disso, buscavam reparação.
} 
empresa ré - Saint-Gobain -, sustentou, sem êxito, que a escolha das partes pela aplicabilidade da lei do estado de Minnesota excluiria a aplicação da Convenção no âmbito daquela relação contratual.

A Corte decidiu que assistia razão a parte autora, pois constatou que a CISG era aplicável ao caso pelo fato de as partes terem estabelecimento em países signatários distintos ${ }^{77}$ e, ademais disso, para que fosse afastada a sua aplicação, far-se-ia necessária a expressa manifestação das partes nesse sentido, não bastando a escolha da lei de um estado norte americano específico para rechaçar essa incidência.

Isso se justificou, principalmente, pelo fato de que o intuito da elaboração da CISG foi justamente trazer uniformidade e, junto a ela, segurança jurídica ao âmbito do comércio internacional de mercadorias. Deste modo, para que a Convenção não seja aplicada a um contrato firmado entre partes com estabelecimento em Estados contratantes, há de existir uma previsão expressa de opt-out, capaz de permitir o seu afastamento. ${ }^{78}$

Deste modo, no casso narrado, não houve disposição contratual optando pela aplicação da CISG, mas o juízo responsável pela resolução de conflito judicial que se originou entre as partes reconheceu sua aplicação - diante da arguição dos autores em idêntico sentido - o que configurou a incidência da Convenção no caso concreto.

Um caso interessante julgado pelo Tribunal Supremo Popular de Cuba, em 2008, envolvia uma empresa cubana e outra sul africana, que celebraram

\footnotetext{
${ }^{77}$ A parte autora (compradora no contrato de compra e venda de mercadorias) tinha estabelecimento nos Estados Unidos, enquanto a empresa ré (vendedora) estava estabelecida no Canadá.

78 "The court cited with approval another court's statement that 'an affirmative opt-out requirement promotes uniformity and the observance of good Faith in international trade, two principles that guide interpretation of the CISG' In support of its approach, the court stated that '[a] majority of courts interpreting similar choice-of-law provisions... conclude that a reference to a particular state's law does not constitute an opt-out of the CISG; instead, the parties must expressly state that the CISG does not apply.'" Identificação do caso, resumo, comentários e acesso à íntegra da decisão estão disponíveis em <https://iicl.law.pace.edu/cisg/case/united-states-state-minnesota-county-hennepin-district-courtfourth-judicial-district-84> Acesso em: 20 mai. 2019.
} 
contrato de compra e venda de equipamentos para celular, em que a empresa cubana figurava como compradora e a africana como vendedora.

O caso em referência interessa, pois não envolvia apenas o comércio de mercadorias, mas também questões relacionadas a títulos de crédito, o que foge do escopo de aplicação da Convenção.

Nesse cenário, as partes haviam determinado, em sede contratual, que seria aplicada a lei cubana à relação entre elas estabelecida, não tendo feito qualquer menção à CISG. A corte cubana, reconheceu que as partes poderiam, com base no artigo 6 da Convenção, excluir sua aplicação expressa ou implicitamente. No entanto, entendeu que a opção pela aplicação da lei cubana não configurava tal renúncia implícita, já que a CISG já havia sido ratificada por Cuba em 1995, estando em vigor no país desde então.

Deste modo, o tribunal cubano reconheceu a CISG como legislação aplicável ao contrato, sob todos os aspectos concernentes à compra e venda de mercadorias e, quanto às questões envolvendo títulos de crédito, seria aplicado o Código Civil cubano. A corte estipulou, ainda, que as lacunas eventualmente existentes na CISG que impedissem a resolução do conflito seriam também preenchidas através da aplicação da lei de Cuba.

Assim, nessa decisão, a corte entendeu que a mera manifestação das partes quanto à aplicabilidade de lei doméstica ao contrato não exclui a aplicabilidade da CISG, que, no caso de Cuba, integra o seu ordenamento jurídico interno.

Em 2013, decisão proferida pela Corte de Apelação de Rouen, França, reconheceu a aplicação da CISG ao conflito judicial que teve como origem contrato firmado entre partes com estabelecimento na França e na Itália - 
ambos Estados signatários da Convenção -, de compra e venda de rolos de filme de polipropileno. ${ }^{79}$

No caso, a sociedade vendedora era a estabelecida na Itália, enquanto a compradora tinha estabelecimento na França. O conflito se deu em virtude de um defeito apresentado em dos lotes da mercadoria comercializada, o que foi identificado e comunicado por um dos clientes da empresa francesa em Portugal. Em função disso, a empresa francesa ajuizou ação indenizatória perante o Tribunal de Comércio de Dieppe, em busca da reparação pelo prejuízo sofrido $^{80}$.

A decisão de primeira instância julgou procedentes os pedidos da autora, condenando a sociedade italiana ao pagamento de indenização. A decisão, no entanto, foi alvo de recurso de apelação.

Em sede de apelação, portanto, o juízo competente reconheceu ser aplicável a Convenção de Viena de 1980, que constitui o direito substancial francês aplicável à compra e venda internacional de mercadorias, exceto quando há manifestação das partes pela sua exclusão - o que não foi o caso.

Na decisão, o reconhecimento da aplicação da CISG foi capaz de solucionar a controvérsia originada pelas partes quanto à existência de uma cláusula contratual que limitaria a garantia prevista quanto às mercadorias comercializadas no caso.

Ocorre que, enquanto autora da demanda judicial, a empresa francesa alegava não ser aplicável a cláusula de limitação de responsabilidade da

\footnotetext{
${ }^{79}$ A íntegra a decisão do caso n ${ }^{\circ}$ 12/02078 da Corte de Apelação de Rouen encontra-se disponível em <http://www.cisg.fr/pdf/20131003CARouen.pdf> Acesso em: 20 mai. 2019.

${ }^{80} \mathrm{O}$ prejuízo se justificava principalmente no dano à imagem que a empresa francesa sofrera diante de seus clientes. Veja-se: “... atendu qu'elle (la societé italienne) savait que ses produits étaient distinés à être revendus par la societé $P$ (française); que le dommage résultant de l'atteinte à l'image de la société $P$ auprês de clientes destinataires des produits était donc normalement prévisible par les cocontractants au moment de la vente; Attendu que compte tenu de sa nature et de son ampleus ce chef de préjudice sera compense par une indemnité de 3000 euros;".
} 
empresa ré, já que não havia concordado expressamente com a referida disposição e, principalmente porque a CISG dispõe que o vendedor - no caso, a empresa italiana - deveria indenizar integralmente o comprador pelos prejuízos em que incorrer em virtude de defeito da mercadoria comercializada $^{81}$.

Deste modo, ao reconhecer que não havia manifestação expressa das partes no sentido de afastar a aplicação da Convenção à relação contratual entre elas estabelecida, o juízo entendeu que a referida norma era aplicável e, por conta disso, a empresa ré estaria obrigada a reparar integralmente o dano causado à compradora das mercadorias defeituosas.

Outro caso curioso envolvendo a aplicação da CISG, desta vez no Brasil, é o da apelação em que figuraram como partes Anexo Comercial Importação e Distribuição Ltda. - EPP (“Anexo Comercial”) e Noridane Foods S.A ("Noridane Foods"), de $2017^{82}$.

Trata-se, originalmente, de ação de rescisão do contrato celebrado pelas partes, cumulada com pedido de indenização por danos materiais, movida pela Noridane Foods em face da Anexo Comercial. O contrato dispunha sobre a compra e venda de 162 toneladas de pés de galinha congelados, a serem pagos em moeda corrente americana.

A Noridane Foods optou pelo ajuizamento da ação por não haver recebido as mercadorias conforme contratado. Em primeira instância, a decisão proferida pela Vara Judicial da Comarca de Estância Velha julgou parcialmente procedente o pleito autoral, declarando rescindido o contrato de compra e venda internacional e condenando a Ré à restituição dos valores

\footnotetext{
${ }^{81} \mathrm{O}$ que na decisão foi denominado como "principe d'indemnisation intégrale du préjudice de l'acquéreur".

82 Apelação no 00000409-73.2017.8.21.7000. Tribunal de Justiça do Rio Grande do Sul, Brasil. Decisão proferida em 14 de fevereiro de 2017. A íntegra da decisão pode ser encontrada em <http://www.cisgspanish.com/wp-content/uploads/2017/03/Apela\%C3\%A7\%C3\%A3oC\%C3\%ADvel-n.\%C2\%BA-70072362940-3-1.pdf>. Acesso em: 20 mai. 2019.
} 
recebidos até aquele momento. Inconformada com a decisão, Anexo Comercial ajuizou apelação, onde se decidiu pela manutenção da sentença retro.

Em sede de apelação, portanto, o acórdão primeiramente reconheceu o caráter internacional do contrato de compra e venda. ${ }^{83}$ Posteriormente, o órgão julgador suscitou ser perfeitamente possível a aplicabilidade da CISG no caso concreto, mesmo que esta ainda não se encontrasse em vigor no Brasil no momento em que o contrato foi celebrado entre as partes.

Ocorre que, em princípio, não se vislumbraria a aplicação da CISG, tendo em vista que o contrato em questão fora celebrado em 01 de julho de 2014, ou seja, antes da entrada em vigor da Convenção no Brasil, que se deu apenas em 16 de outubro do mesmo ano.

À ocasião, o juízo de segunda instância justificou o reconhecimento da observância da CISG no caso por entender não haver qualquer impedimento ao uso da Convenção como fonte jurídica aplicável ao mérito.

Deste modo, deu maior importância ao teor da CISG - a que ela se propõe -, a sua ampla adesão no plano internacional e ao fato de o Brasil ter se tornado um dos Estados signatários antes de firmado o contrato - em 01 de abril de 2014 -, do que à posição estritamente positivista adotada pelo Superior Tribunal Federal (STF), no sentido de que os tratados internacionais dependerão de decreto presidencial para terem eficácia interna.

\footnotetext{
${ }^{83}$ Nesse caso, as partes em momento algum firmaram instrumento contratual formal, mas a existência do vínculo foi reconhecida tanto pelo juízo de piso quanto pelo de segundo grau em virtude das circunstâncias do caso, tais quais o pagamento de uma parcela inicial pela Noridane Foods, bem como a aceitação pela Ré, no trâmite processual, de que havia acordado com a parte Autora a entrega das 162 toneladas de pés de galinha congelados. Posto isso, o caráter internacional do contrato foi constatado, pois verificada a existência de seu "efeito internacionalizante" - conforme nomenclatura utilizada por Maristela Basso - já que a empresa compradora possuía domicílio na Dinamarca e a vendedora, no Brasil. Ademais disso, as obrigações referentes à execução do contrato dividir-se-iam entre Brasil e Hong Kong, China, em virtude da transferência de propriedade das mercadorias e sua entrega.
} 
Nessa perspectiva, entendeu que a CISG representaria a melhor fonte de usos e costumes do comércio internacional de mercadorias, o que faria valer a sua aplicação ao caso, mesmo antes de sua entrada em vigor no Brasil. ${ }^{84}$ Desta forma, a decisão aplicou a Convenção como costume, não como norma de direito positivo.

A decisão justifica a aplicabilidade da CISG ao caso concreto também pelo fato de a Convenção enaltecer o princípio da autonomia privada e da boa fé objetiva na condução das relações comerciais internacionais.

Por fim, considerou obsoletos os elementos de conexão contidos da LINDB, entendendo que deveriam ser substituídos pela aplicação direta da Convenção, que figura como a "nova lex mercatória" no âmbito do comércio internacional de mercadorias. ${ }^{85}$

Também em 2017, nos Estados Unidos, a CISG foi reconhecida como lei aplicável ao contrato de compra e venda internacional de mercadorias celebrado entre as partes na lide processual Nucap Industries, Inc. e Nucap US Inc.("Nucap") v. Robert Bosch LLC e Bosch Brake Components LLC (" $\underline{\text { Bosh" }} .{ }^{86}$

Bosh e Nucap mantinham relações comerciais concernentes ao fornecimento de pastilhas de freio ("brake pads").

\footnotetext{
84 “... há possibilidade de antecipação dos efeitos jurídicos das convenções não ratificadas, pelo juiz nacional, quando ele aplica o texto como forma de 'manifestação doutrinária', prova dos usos e costumes internacionais ou, ainda, como direito estrangeiro." BASSO, Maristela. Curso de direito internacional privado. São Paulo: Atlas, 2014, p.78.

85 “Assim, a conclusão a que se chega é que também o princípio da proximidade - ensejando abordagem flexível e atenta 'às realidades sociais e econômicas que embasam o fenômeno jurídico' redunda na aplicação da Convenção de Viena de 1980 e dos Princípios Unidroit para o enfretamento do mérito, cabendo aqui ressaltar que a doutrina autoriza o uso da 'nova lex mercatoria' como Direito aplicável às obrigações contratuais multiconectadas, mormente à luz do caráter obsoleto dos elementos de conexão dados pela LINDB."

${ }^{86}$ Caso no 15 C 2207. Corte Distrital de Illinois, Estados Unidos. Decisão proferida em 31 de Março de 2017.
} 
Nesse caso, as partes discordavam sobre a lei aplicável à disputa, apesar de que ambos concordassem que a CISG se aplicava em algum grau. Deste modo, diferiam sobre em relação a quais aspectos da Convenção haveriam decidido pelo opt out, aplicando a estes a lei do estado americano de Illinois.

Deste modo, os autores da demanda entendiam que a CISG deveria ser a legislação usada para determinar o escopo de sua aplicação ao caso concreto, enquanto as empresas rés defendiam caber à lei do estado de Illinois essa identificação.

A Corte Distrital de Illinois decidiu, portanto, que os limites da aplicação da CISG ao caso deveriam ser definidos pela própria Convenção, em respeito ao princípio da supremacia da Constituição, que declara que um tratado ratificado pelo Congresso norte americano tem a natureza de lei suprema, estando hierarquicamente acima da lei de Illinois e, portanto, prevalecendo em relação a ela.

\subsection{Casos nos quais foi reconhecida a inaplicabilidade da CISG}

A maioria das decisões envolvendo a aplicabilidade - ou não - da CISG fundamenta que, para que seja identificado o opt out, é necessária a afirmativa clara e inequívoca das partes nesse sentido. Assim, não basta que uma delas se manifeste contra a sua aplicação, mas que haja uma convergência da vontade das partes nessa direção.

Alguns tribunais, no entanto, consideram que a Convenção pode ser excluída implicitamente, apesar de o seu texto não defender essa posição expressamente. ${ }^{87} \mathrm{O}$ que se sabe, no entanto, é que, quando da elaboração do texto normativo, sugestões quanto à inclusão de disposição referindo-se à

\footnotetext{
${ }^{87}$ Em decisão proferida em 21 de janeiro de 2010 pela Corte Distrital Americana do Leste da Califórnia, por exemplo, foi firmado entendimento no sentido de que, para que não se aplique a Convenção, basta que o contrato contenha cláusula de escolha de legislação aplicável.
} 
necessidade de a exclusão da aplicação da Convenção ter de se dar de maneira expressa foram rejeitadas. ${ }^{88}$

Certo é que, para identificar o opt out, é necessário que o órgão julgador faça uma avaliação minuciosa das particularidades do caso concreto.

Foi através dessas análises, inclusive, que alguns posicionamentos foram adotados por grande quantidade de tribunais, como por exemplo, o reconhecimento da exclusão da CISG quando as partes optam pela aplicação da legislação de um Estado não contratante para reger o contrato.

Nesse caso, por mais que as partes contratantes tenham estabelecimento em países signatários da Convenção, ao optar pela lei de um Estado não contratante para reger os direitos e obrigações originados da relação contratual entre elas estabelecida, entende-se que estão exercendo seu direito ao opt out da CISG, por mais que não o convencionem expressamente.

No entanto, o modo mais seguro do ponto de vista jurídico - levando em consideração o entendimento majoritário da jurisprudência - de excluir a aplicação da CISG seria através da inclusão de disposição contratual expressa nesse sentido.

É o exemplo da cláusula destacada abaixo, extraída de contrato internacional de compra e venda de material didático, firmado em 2019 entre uma empresa com estabelecimento no Brasil e outra em Hong Kong:

\subsection{Governing Law}

This Agreement shall be governed by and construed in all respects in accordance with the laws of New York, USA excluding: (i) any conflicts of law provisions now or hereafter in force; and (ii) the provisions of the United Nations Convention on Contracts for the International Sale of Goods.

\footnotetext{
${ }^{88}$ Digest of Case Law on the United Nations Convention on Contracts for the International Sale of Goods. Uncitral. Disponível em <https://www.uncitral.org/pdf/english/clout/CISG-digest-2012-e.pdf>. Acesso em: 20 mai. 2019.
} 
Neste caso, não resta dúvida quanto à vontade das partes de excluir a aplicação da Convenção.

Veja-se: apesar de terem escolhido como lei aplicável a do estado norteamericano de Nova York, o que levaria a aplicação da Convenção, já que os Estados Unidos são signatários do tratado, há uma rejeição expressa constante do contrato firmado pelas partes no sentido de vetar sua aplicação.

Neste ponto, cumpre salientar que quando a opção das partes pela lei aplicável refere-se ao ordenamento jurídico de um Estado não signatário, a recusa à aplicação da Convenção se dá de forma muito mais clara. No entanto, a divergência na jurisprudência se instaura quando é escolhida lei de Estado contratante na cláusula de choice of law.

Algumas cortes e tribunais arbitrais entendem que, ao menos quando a cláusula de choice of law refere-se à aplicação "exclusiva" da legislação de um Estado contratante, isso acarretaria numa exclusão implícita da CISG.

Esse, no entanto, não é o entendimento jurisprudencial majoritário, que reconhece que a CISG integra o ordenamento jurídico dos países signatários, motivo pelo qual é perfeitamente aplicável, inclusive quando as partes optam por aplicar "exclusivamente" a legislação de um determinado Estado contratante.

Em decisão proferida pela Suprema Corte Australiana de Nova Gales do Sul, em 2012, no caso Venter v. Illona MY Ltd.("Illona”), o juízo se pronunciou especificamente sobre o tema, ao afirmar que a CISG não seria aplicável ao caso por ter sido expressamente excluída pelas partes. ${ }^{89}$

De fato, no caso não havia dúvida quanto à inaplicabilidade da Convenção, tendo em vista que as partes haviam firmado contrato com

\footnotetext{
${ }^{89}$ Caso no SC 2009/287072 . Suprema Corte de Nova Gales do Sul, Austrália. Decisão proferida em 24 de agosto de 2012.
} 
cláusula de choice of law não só optando pela aplicação da legislação alemã, como especificaram que a aplicação da CISG estaria excluída. ${ }^{90}$

No caso Industrias Magromer Cueros y Pieles S.A. ("Magromer") v. Sociedad Agrícola Sacor Limitada ("Sacor"), julgado em 2008, no Chile, não foi reconhecida a aplicação da CISG, pois a corte entendeu que esta havia sido implicitamente suprimida pela escolha de ordenamento jurídico doméstico aplicável ao contrato. ${ }^{91}$

O caso supramencionado foi o primeiro em que se discutiu a possível aplicação da Convenção de Viena de 1980 pelos tribunais chilenos.

Magromer era uma sociedade com estabelecimento na Argentina e figurava como compradora na relação contratual, enquanto Sacor era uma empresa com sede no Chile, que vendia peles/lã de origem chilena. Dito isso, a manufatura de diversos produtos pela compradora dependia da entrega da matéria prima comercializada pela vendedora, o que se deu por diversos anos de relações contratuais entre elas.

Quando, em 2002, o vendedor não conseguiu entregar a quantidade de lã que havia sido acordada com o comprador, isto gerou um impacto negativo na sua produção, o que ocasionou um grave prejuízo em relação à diminuição significativa na sua produção, que acabou impactando a imagem da Magromer e sua marca. Esse foi o estopim para o ajuizamento da ação pela compradora. ${ }^{92}$

\footnotetext{
${ }^{90}$ Nesse caso, a Sra. Venter ajuizou ação contra a empresa alemã em virtude da morte de seu marido, Sr. Venter, que faleceu em virtude de um acidente a bordo do iate que haviam adquirido junto à ré. A demandante alegava que a morte de seu marido se deu em virtude de um defeito no iate comprado da Illona, o que originou o inadimplemento contratual capaz de embasar o pleito autoral.

${ }^{91}$ Caso n ${ }^{\text {1 }}$ 1782-2007. Corte Suprema (CSU), Chile. Decisão proferida em 22 de setembro de 2008. A íntegra da decisão pode ser encontrada em <http://www.cisgspanish.com/wpcontent/uploads/2013/02/C.-SupremaChile22.09.2009.pdf>. Acesso em: 20 mai. 2019.

92 "La compradora demandó ante los tribunales chilenos a la vendedora por incumplimiento del contrato, señalando que a la finalización del plazo acordado la vendedora sólo entregó 89.000 cueros, dejando un saldo de 61.000 unidades que a la postre fueron vendidas a otros compradores. Ante este hecho, en la demanda se pidió decretar la indemnización de perjuicios derivados del incumplimiento parcial del contrato como pretensión principal, comprendiendo dentro de tal indemnización el lucro
} 
Em sua defesa, a vendedora alegou, dentre outros fatores, que a autora da demanda, com base no artigo 1.489 do Código Civil do Chile, não poderia ter como pedido principal da demanda o pleito indenizatório e que deveria ter recorrido primeiramente à resolução ou execução do contrato.

A referida tese foi acolhida pelo juízo de primeiro grau, que negou o pedido da empresa argentina com base no Direito chileno. A compradora apelou da decisão, que foi ratificada pela Corte de Apelações de Punta Arenas em 2007, bem como pela Corte Suprema, em 2008.

A decisão das cortes chilenas se deu nesse sentido por entenderem que haveria ocorrido a renúncia tácita à CISG, já que a Magromer reivindicou sua aplicação apenas no momento da apelação, não tendo suscitado a questão em primeira instância - nem em sede inicial, nem em réplica.

É interessante observar que, via de regra, a Convenção seria aplicável ao caso, já que ambas as empresas tinham estabelecimento em Estados contratantes, que já haviam internalizado a Convenção aos seus respectivos ordenamentos jurídicos domésticos no momento em que o contrato fora firmado entre as partes. ${ }^{93}$

Apesar disso, como a CISG valoriza de maneira especial o princípio da autonomia da vontade, permite-se que sua aplicação seja excluída pelas partes contratantes ou que, ainda, estas estabeleçam alterações em suas disposições. Os tribunais chilenos, com base nisso - no artigo 6 da Convenção, portanto -

cesante originado, a juicio de la compradora, en las utilidades "normales y razonables" dejadas de percibir porlas ventas de las prendas que habría fabricado con el cuero objeto del contrato, además de daños a la imagen y a la marca. La compradora no solicitó previamente la resolución del contrato o la ejecución forzosa de la prestación."

ALBÁN, Jorge Oviedo, Exclusión tácita de la ley aplicable e indemnización de perjuicios por incumplimiento de un contrato de compraventa internacional (a propósito de reciente jurisprudencia chilena), International Law, Revista Colombiana de Derecho Internacional, v. 14, p. 191-219, 2009.

93 “...la Convención resultaba aplicable de forma evidente, con exclusión de las leyes nacionales, sean las argentinas o las chilenas. Ello, pues el contrato se celebró entre dos partes establecidas en diferentes Estados parte de la Convención en fecha muy posterior a su entrada en vigor, teniendo como objeto la venta de bienes muebles corporales a cambio de un precio." ALBÁN, Jorge Oviedo. Op. cit. 
justificaram a aplicação do ordenamento jurídico chileno, excluindo a aplicabilidade da CISG, por entenderem que esta havia sido rejeitada tacitamente pelas partes.

Deste modo, a jurisprudência chilena se manifestou no sentido de que a exclusão tácita da CISG pode se dar pela não invocação de sua aplicação em atos processuais, apesar de as partes não terem escolhido previamente a lei de um Estado específico para reger o contrato celebrado entre elas.

O entendimento da corte chilena em 2008 não foi o pioneiro nesse sentido. Em 2002, um caso julgado pela Corte Distrital de Shangai também já havia deixado de aplicar a Convenção de Viena de 1980 em virtude da falta de abordagem processual das partes nesse sentido (Grammatex International S.r.l v. Shangai Eastern Crocodile Apparels Co. Ltd.). ${ }^{94}$

O processo teve origem no inadimplemento do contrato de venda de roupas firmado entre uma empresa italiana e outra chinesa e, apesar de presentes todos os requisitos para aplicabilidade da CISG e da ausência de evidências que levassem à conclusão de que as partes tinham a intenção de eliminar a aplicação da Convenção, a corte chinesa deixou de emprega-la, simplesmente pelo fato de as partes não terem requerido, no decorrer do processo, que fosse aplicada.

Em 1995, idêntico entendimento foi firmado pelo tribunal arbitral da Corte Internacional de Comércio de Paris. No caso, uma empresa vendeu máquina de uso médico e, após ter sido instalada, o comprador percebeu uma série de problemas operacionais no produto. Em virtude do caráter defeituoso

\footnotetext{
${ }^{94}$ Caso Hu Yi Zhong Min Wu (Shang) Chu Zi Di No. 32. Corte Distrital de Shangai. Decisão proferida em 21 de Agosto de 2002.
} 
da mercadoria comercializada, o comprador instaurou o procedimento perante a corte arbitral. ${ }^{95}$

A decisão se deu no sentido de respeitar a estratégia processual das partes, que não mencionaram a aplicabilidade da Convenção durante o procedimento arbitral e tampouco o haviam feito quando firmaram o compromisso arbitral, em sede contratual. Ademais disso, ambas as partes manifestaram-se a favor da aplicação da lei francesa ao caso concreto, o que foi respeitado pelo tribunal arbitral.

\subsection{Casos em que foi reconhecida a aplicação parcial da CISG}

O artigo 6 da Convenção admite não só a hipótese de excluir totalmente sua aplicação, de acordo com a vontade das partes, mas também de abdicar e/ou modificar algumas de suas previsões.

A escolha pela alteração de disposições da CISG encontra óbice tão somente no que diz respeito aos seus artigos 96 e 12. Deste modo, caso uma das partes tenha estabelecimento em um Estado contratante que tenha feito a reserva do artigo 96, não será possível as partes afastarem ou modificarem os efeitos do artigo 12.

Do estudo dos casos que tratam da aplicabilidade da Convenção, nota-se que, em sua maioria, tratam da manifestação da vontade das partes pela sua exclusão de sua aplicação no todo, ou pela sua aplicação, também em sua integralidade.

Deste modo, não foram encontrados, durante as pesquisas feitas, casos nos quais se discutiu a aplicação parcial da CISG ou a manifestação das partes no sentido de afastar apenas alguns efeitos determinados previstos no texto da Convenção, ou de alterá-los.

\footnotetext{
${ }^{95}$ Caso no ${ }^{0}$ 8453. Corte Internacional de Comércio (ICC), Paris, França. Decisão proferida em Outubro de 1995.
} 


\section{CONSIDERAÇÕS FINAIS}

Ao concluir o presente trabalho, resta evidente a importância do princípio da autonomia da vontade para o direito privado, tanto a nível nacional quanto internacional, motivo pelo qual ganhou tamanho destaque na Convenção de Viena de 1980.

Resumidamente, é possível dizer que, no Direito Civil, a autonomia da vontade é caracterizada pela capacidade que detêm os particulares de definirem normas capazes de regulamentar as relações entre eles estabelecidas, da forma que melhor atenda seus interesses, e desde que em conformidade com o ordenamento jurídico estatal aplicável.

Para o Direito Internacional Privado, o princípio é especialmente importante do ponto de vista dos contratos internacionais, onde se faz possível escolher - direta ou indiretamente - a lei aplicável ao negócio jurídico celebrado entre as partes.

No entanto, essa autonomia das partes para escolha da lei que irá incidir sobre um contrato internacional não se dá de maneira simples, tendo em vista que cada ordenamento jurídico doméstico lida com a questão de uma maneira, conforme suas disposições legislativas de DIPri - podendo reconhecer a legitimidade das partes para escolherem, de acordo com sua vontade, a lei aplicável, ou não.

Ademais disso, historicamente, a regra para estipulação da lei aplicável aos contratos internacionais era a do local de celebração, tendo o princípio da autonomia da vontade ganhado maior notoriedade apenas a partir da segunda metade do século XIX, graças a avanços jurisprudências da Inglaterra e Estados Unidos nesse sentido, que foram seguidos por outros países europeus. 
Quanto à Convenção das Nações Unidas sobre Compra e Venda Internacional de Mercadorias - surgida em 1980 como uma tentativa de uniformizar a regulamentação do comércio internacional em um mundo cada vez mais globalizado e, consequentemente, com transações comerciais cada vez mais intensas -, foi conferido destaque fundamental à autonomia da vontade, em seu artigo 6.

A CISG, que foi amplamente aceita a nível internacional, contando, atualmente, com 89 Estados signatários, tem seu sucesso atribuído não somente ao fato de ter sido elaborado um texto equilibrado para as partes em um contrato de compra e venda, e de fácil entendimento, mas principalmente pelo protagonismo da autonomia da vontade, o que lhe garante maior flexibilidade.

Apesar de em um primeiro momento poder parecer contraditório, é justamente a previsão contida na CISG de as partes contratantes poderem prever a exclusão de sua aplicação, que configura um dos principais motivos para sua ampla adesão pelos Estados signatários.

Isso se explica pelo fato de os agentes do comércio internacional, apesar de reconhecerem a importância de uma regulamentação sólida - e por sólida entenda-se ratificada por um grande número de países de importância relevante do ponto de vista da atuação no comércio internacional -, valorizarem também sua liberdade de poder afastar a incidência da norma, caso assim lhes convier.

A partir do estudo de casos concretos, é possível chegar a algumas conclusões quanto ao entendimento dos tribunais em relação à aplicabilidade da CISG.

Primeiramente, para reconhecer a aplicabilidade da Convenção no caso concreto, o tribunal irá, antes de mais nada, analisar se houve manifestação da vontade das partes no sentindo de afastar a incidência da norma. 
Outro aspecto observado foi que a escolha da lei de um local específico para reger o contrato não implica, por si só, no reconhecimento do opt out. Isso irá depender do fato de o ordenamento jurídico escolhido pelas partes pertencer ou não a um Estado contratante da Convenção. Deste modo, caso tenham optado pela aplicação da lei de um país signatário, estar-se-á diante, consequentemente, da aplicação da CISG. Se, no entanto, for escolhida lei de Estado não contratante, estar-se-á diante do opt out. Essa é a visão majoritária dos tribunais.

No que tange à identificação do opt out pelos tribunais, resta claro que as decisões não são unânimes no sentido de ser necessária a manifestação expressa das partes, ou se a incidência da Convenção pode ser afastada tacitamente. A jurisprudência internacional tem se fixado pela análise atenta das características do caso concreto, a fim de se determinar se houve ou não exclusão da norma.

Ainda quanto à inaplicabilidade da Convenção, é possível observar que alguns tribunais já deixaram de ministra-la não por identificarem manifestação das partes nesse sentido, mas por inferirem que esta seria a sua intenção, levando em consideração a falta de abordagem processual pela aplicação da norma.

Importa mencionar que, apesar da previsão contida na Convenção de que sua aplicação pode se dar de maneira parcial, não foram encontrados casos nos quais isso foi discutido perante juízo jurisdicional ou arbitral.

Isso, no entanto, não implica dizer que os agentes internacionais não optam pela aplicação parcial da Convenção, mas apenas que ainda não surgiram conflitos registrados nos arquivos utilizados como fonte de pesquisa sobre o tema. 
Certo é que, pelo número de casos envolvendo a aplicabilidade ou inaplicabilidade da CISG - em sua totalidade - encontrados durante a pesquisa que culminou na elaboração do presente trabalho, pode-se concluir que a opção dos agentes do comércio internacional por aplicar ou não a Convenção é muito mais frequente do que sua manifestação de vontade no sentido de aplicá-la parcialmente ou modificar seus efeitos.

Quanto à observância da Convenção no Brasil e a visão dos tribunais brasileiros em relação a essa questão, constata-se que tivemos tímidos avanços ao conferir efetividade à norma, que desde 2014 integra nosso ordenamento jurídico.

Até 2016, segundo estudo desenvolvido pelo Comitê Brasileiro de Arbitragem ${ }^{96}$, não existiam casos de jurisdição nacional brasileira que houvessem aplicado a CISG como norma de direito material, mesmo que seja essa sua função primária.

Fato é que, em 2017, o caso Anexo Comercial v. Noridane Foods, cujo conteúdo foi abordado no presente trabalho, reconheceu a aplicabilidade da Convenção, mesmo que como fonte de usos e costumes do comércio internacional de mercadorias e não como norma imperativa do ordenamento jurídico pátrio.

Por todo o exposto, pode-se dizer que, de maneira geral, a Convenção de Viena de 1980 atingiu seu objetivo de regulamentar a compra e venda de mercadorias a nível internacional, trazendo segurança jurídica para os agentes do comércio além-fronteiras, ao passo que assegura a autonomia da vontade das partes na condução de seus negócios jurídicos.

\footnotetext{
${ }^{96}$ O relatório da pesquisa desenvolvida pelo Grupo de Estudos sobre a Convenção sobre Compra e Venda Internacional de Mercadorias e Arbitragem do Comitê Brasileiro de Arbitragem (CBAr) pode ser encontrado em <http://cbar.org.br/site/wp-content/uploads/2017/03/Relatorio-Pesquisa-Juris-CISG2016_versao-consolidada-e-revisada_FINAL.pdf>. Acesso em: 03 jun. 2019.
} 
Além disso, a pesquisa feita pelo CBAr, a qual já se fez referência, constatou que a Convenção, desde 1980, vem se consolidando como instrumento de soft law, tendo inspirado ordenamentos jurídicos nacionais como da Argentina e da China - o que amplia a harmonização entre ordens jurídicas domésticas - e servindo como fonte de Direito para a tomada de decisões pelos tribunais de diversos países.

No entanto, espera-se que a consolidação da Convenção e sua ampla aplicação - tanto pelos agentes privados, quanto pelos tribunais nacionais como se dá em países da América do Norte e Europa, se reproduza nos países em desenvolvimento - da América Latina, Ásia e África - que, apesar de, em sua maioria, terem ratificado a Convenção, ainda não foram capazes de apresentar ampla adesão à CISG na prática comercial e jurisdicional, ainda mais quando comparados aos países desenvolvidos. 


\section{REFERÊNCIAS BIBLIOGRÁFICAS}

AGUIAR JÚNIOR, Ruy Rosado de. Aspectos da Convenção de Viena sobre a compra e venda internacional de mercadorias (CISG) - 1980. Texto básico da palestra Resolução e adimplemento substancial na CISG, proferida em Curitiba, em 20 de março de 2014.

ALBÁN, Jorge Oviedo, Exclusión tácita de la ley aplicable e indemnización de perjuicios por incumplimiento de un contrato de compraventa internacional (a propósito de reciente jurisprudencia chilena), International Law, Revista Colombiana de Derecho Internacional, v. 14, p. 191-219, 2009.

AMARAL NETO, Francisco dos Santos. A autonomia privada como princípio fundamental da ordem jurídica. Perspectivas estrutural e funcional. Revista de Informação Legislativa, Brasília, v. 26, n. 102, p. 207-230, 1989.

ARAÚJO, Nádia de. A Autonomia da Vontade nos Contratos Internacionais Direito Brasileiro e Países do Mercosul: Considerações sobre a Necessidade de Alterações no Direito Internacional Privado. Revista da Faculdade de Direito da UFRGS, v. 17, 1999, p. 226.

. Direito Internacional Privado: teoria e prática brasileira. Rio de Janeiro: Renovar, 2011.

. Uma visão econômica do Direito Internacional Privado: contratos

internacionais e autonomia da vontade. In: Luciano Benetti Timm. (Org.).

Direito e economia no Brasil. 1. ed. São Paulo: Atlas, 2014.

BAPTISTA, Luiz Olavo. Contratos internacionais da administração pública: novos rumos?. In: MELLO, Celso Antônio Bandeira de (Org.). Estudos em homenagem à Geraldo Ataliba. São Paulo: Malheiros, v. 2, 1997.

BASEDOW, Jurgen. Towards a universal doctrine of breach of contract: the impact of the CISG. International Review of Law and Economics, v. 25, p. 487-500, 2005.

BASSO, Maristela. A Autonomia da Vontade nos Contratos Internacionais do Comércio. Revista da Faculdade de Direito da UFRGS, v. 12, p. 198, 1996.

. Curso de direito internacional privado. São Paulo: Atlas, 2014. 
CASTRO, Amilcar de. Direito internacional privado. Rio de Janeiro: Renovar, 2008.

Digest of Case Law on the United Nations Convention on Contracts for the International Sale of Goods. Uncitral. Disponível em <https://www.uncitral.org/pdf/english/clout/CISG-digest-2012-e.pdf>. Acesso em: 20 mai. 2019.

DOLINGER, Jacob. A livre escolha pelas partes da lei aplicável nos contratos internacionais. Revista de Direito do Estado, Rio de Janeiro, Renovar, $\mathrm{n}^{\circ} 2$, 2006.

FAUVARQUE-COSSON, Bénédicte. Towards a Renewed Universalism in Law, In: Diogenes, n. 219. SAGE, 2008, p. 56. In: GLITZ, E. Z. Frederico. Contrato, globalização e lex mercatória. Convenção de Viena 1980 (CISG), Princípios Contratuais UNIDROIT (2010) e INCOTERMS (2010). São Paulo: Editora Clássica, 2014, p. 61.

FERRARI, Franco. The CISG and its Impact on National Legal Systems. Munich: Editora sellier. European law publishers GmbH, 2008.

FERRARI, Franco. What Sources of Law for Contracts for the International Sale of Goods? Why One has to Look Beyond the CISG. Verona: International Review of Law and Economics, 2005.

FORGIONI, Paula A. Teoria geral dos contratos empresariais. São Paulo: Revista dos Tribunais, 2009.

FRADERA, Véra Maria Jacob de; MOSER, Luiz Gustavo Meira (Org.). A compra e venda internacional de mercadorias: estudos sobre a Convenção de Viena de 1980. São Paulo: Atlas, 2011.

GLITZ, E. Z. Frederico. Contrato, globalização e lex mercatória. Convenção de Viena 1980 (CISG), Princípios Contratuais UNIDROIT (2010) e INCOTERMS (2010). São Paulo: Editora Clássica, 2014.

HONNOLD, John. O. Uniform Law for International Sales under the 1980 United Nations Convention, 3rd edition, 1999.

KAHN-FREUND, O. General problems of private international law. Collected Courses of the Hague Academy of International Law. The Hague: Martinus Nijhoff, 1974. v. 143. p. 342. 
LANDO, Ole. The conflict of laws of contracts: general principles. Recueil des Cours, v. 189, 19984-VI, p. 237.

McCLEAN, David. De Conflictu Legum. Perspectives on private international law at the turn of the century. General Course on Private International Law, p. 130 .

NALIN, Paulo. STEINER, C. Renata. Compra e venda internacional de mercadorias: Convenção das Nações Unidas sobre compra e venda internacional de mercadorias. Belo Horizonte: Editora Fórum, 2016.

PEREIRA, Caio Mário da Silva. Instituições de Direito Civil: introdução ao direito civil. 24. ed. Rio de Janeiro: Forense, 2011.

Principles on Choice of Law in International Commercial Contracts. Aprovados em 19 de março de 2015. Disponível em: <https://www.hcch.net/pt/instruments/conventions/full-text/?cid=135> Acesso em: 03 jun. 2019.

REALE, Miguel. Lições preliminares de Direito. São Paulo: Saraiva, 2002.

ROVIRA, Suzan Lee Zaragoza de. Estudo comparativo sobre os contratos internacionais: aspectos doutrinários e práticos. In: RODAS, João Grandino (Coord.) Contratos Internacionais. 2. ed. São Paulo: Revista dos Tribunais, 1995.

SPAGNOLO, Lisa. A glimpse through the kaleidoscope: choices of law and the CISG (Kaleidoscope Part I). SSRN. Disponível em: $\langle$ https://papers.ssrn.com/sol3/papers.cfm?abstract_id=1514130>. Acesso em: 15 abr. 2019.

STRENGER, Irincu. Contratos internacionais do comércio. São Paulo: Revista dos Tribunais, 1992.

TENORIO, Oscar. Lei de Introdução ao Código Civil brasileiro. Rio de Janeiro: Editor Borsoi, 1955.

United Nations Convention on Contracts for the International Sale of Goods (Vienna, 1980). Uncitral. Disponível em: <http://www.uncitral. org/uncitral/uncitral_texts/ sale _ goods/1980CISG_status.html>. Acesso: 15 abr. 2019. 